\title{
Recirculation in the Fram Strait and transports of water in and north of the Fram Strait derived from CTD data
}

\author{
M. Marnela ${ }^{1,2}$, B. Rudels ${ }^{1,2}$, M.-N. Houssais ${ }^{3}$, A. Beszczynska-Möller ${ }^{4}$, and P. B. Eriksson ${ }^{1}$ \\ ${ }^{1}$ Finnish Meteorological Institute, Helsinki, Finland \\ ${ }^{2}$ University of Helsinki, Helsinki, Finland \\ ${ }^{3}$ Laboratoire d'océanographie et du climat: expérimentations et approches numériques (LOCEAN), Unité mixte \\ CNRS/UPMC/IRD/MNHN, Université Pierre et Marie Curie, Paris, France \\ ${ }^{4}$ Alfred Wegener Institute for Polar and Marine Research, Bremerhaven, Germany
}

Correspondence to: M. Marnela (marika.marnela@ fmi.fi)

Received: 13 September 2012 - Published in Ocean Sci. Discuss.: 10 October 2012

Revised: 28 March 2013 - Accepted: 16 April 2013 - Published: 14 May 2013

\begin{abstract}
The volume, heat and freshwater transports in the Fram Strait are estimated from geostrophic computations based on summer hydrographic data from 1984, 1997, 2002 and 2004. In these years, in addition to the usually sampled section along $79^{\circ} \mathrm{N}$, a section between Greenland and Svalbard was sampled further north. Quasi-closed boxes bounded by the two sections and Greenland and Svalbard can then be formed. Applying conservation constraints on these boxes provides barotropic reference velocities. The net volume flux is southward and varies between 2 and $4 \mathrm{~Sv}$. The recirculation of Atlantic water is about $2 \mathrm{~Sv}$. Heat is lost to the atmosphere and the heat loss from the area between the sections averaged over the four years is about $10 \mathrm{TW}$. The net heat (temperature) transport is $20 \mathrm{TW}$ northward into the Arctic Ocean, with large interannual differences. The mean net freshwater added between the sections is $40 \mathrm{mSv}$ and the mean freshwater transport southward across $79^{\circ} \mathrm{N}$ is less than $60 \mathrm{mSv}$, indicating that most of the liquid freshwater leaving the Arctic Ocean through Fram Strait in summer is derived from sea ice melt in the northern vicinity of the strait.
\end{abstract}

In 1997, 2001 and 2003 meridional sections along $0^{\circ}$ longitude were sampled and in 2003 two smaller boxes can be formed, and the recirculation of Atlantic water in the strait is estimated by geostrophic computations and continuity constraints. The recirculation is weaker close to $80^{\circ} \mathrm{N}$ than close to $78^{\circ} \mathrm{N}$, indicating that the recirculation is mainly confined to the south of $80^{\circ} \mathrm{N}$. This is supported by the observations in 1997 and 2001, when only the northern part of the meridional section, from $79^{\circ} \mathrm{N}$ to $80^{\circ} \mathrm{N}$, can be computed with the constraints applied. The recirculation is found strongest close to $79^{\circ} \mathrm{N}$.

\section{Introduction}

Fram Strait with a $2600 \mathrm{~m}$ sill depth is the most important passage between the Arctic Ocean and the Nordic Seas for oceanic transports of heat and freshwater and for sea ice (Fig. 1). On the eastern side of the strait, the West Spitsbergen Current transports warm and saline water towards the Arctic Ocean. On the western side, cold and low salinity surface water is transported southward by the East Greenland Current. The exchanges through the strait play an important role in the heat and freshwater budgets of the Arctic Ocean and have effects on the Arctic sea ice cover as well as on the meridional overturning circulation, which is, at least partly, responsible for the mild climate in the North-Western Europe. The exchanges through the strait have been monitored continuously by hydrographic observations and by direct current measurements since 1997 (Schauer et al., 2008), and irregularly for $30 \mathrm{yr}$. The dynamic nature of the exchanges, with strong boundary currents on both sides of the strait, time variability, intense baroclinic and barotropic eddy activity and substantial recirculation (e.g., Teigen et al., 2011), makes it difficult to accurately define and determine the transports between the Nordic Seas and the Arctic Ocean.

The geostrophic transports of volume/mass, heat and salt/freshwater through Fram strait have previously been 


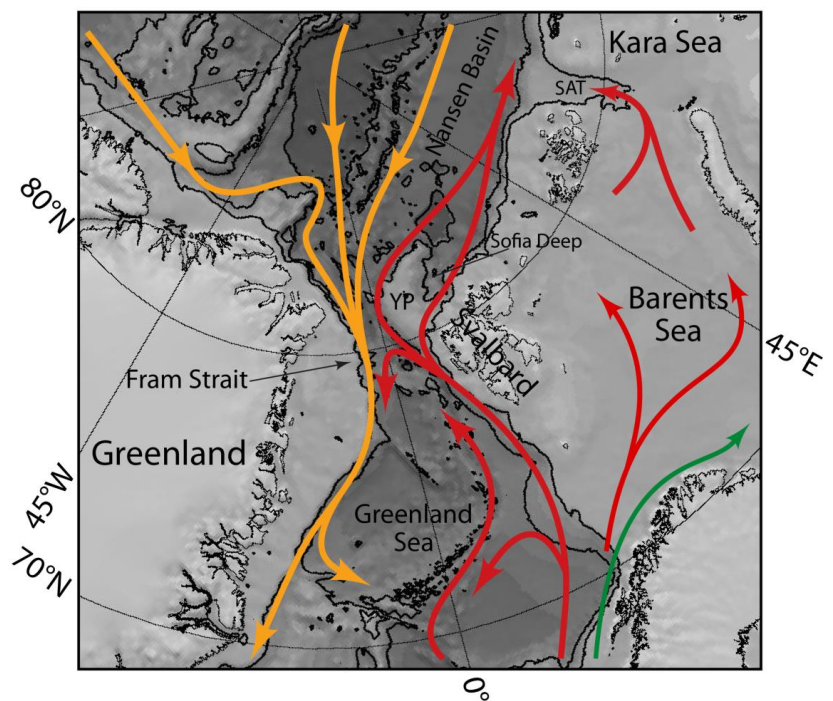

Fig. 1. Fram Strait bathymetry and AW circulation (red AW and orange AAW). Green arrow is Norwegian Coastal Current. YP = Yermak Plateau, SAT = Saint AnnaTrough.

computed from hydrographic sections extending from Greenland to Svalbard with different approaches to determine the reference velocities by, e.g., Palfrey (1967), Rudels (1987), Bourke et al. (1988) and Schlichtholz and Houssais (1999). One recent attempt was made by Rudels et al. (2008), who dealt with the problem of the unknown reference velocities by applying constraints on the salt and volume transports in the deep waters and by evaluating the Arctic Ocean volume and freshwater balances.

The transports have also been estimated from direct current observations; first only in the West Spitsbergen Current (Aagaard et al., 1973; Aagaard and Greisman, 1975) and in the East Greenland Current (Foldvik et al., 1988), but later through a full section at $78^{\circ} 50^{\prime} \mathrm{N}$ that has been monitored continuously since 1997 (e.g., Fahrbach et al., 2001; Schauer et al., 2004, 2008). However, in spite of the large number of moorings, the small scale features of the flow field are still not resolved and undersampling could lead to aliasing of the results and to large variations in the transport estimates.

A seasonal signal in the Fram Strait exchanges has been reported by e.g., Fahrbach et al. (2001) and Schauer et al. (2004) who noted a minimum volume transport in the West Spitsbergen Current in summer with large monthly fluctuations. In the East Greenland Current the seasonal signal is less clear (Fahrbach et al., 2001; Schauer et al., 2004) although de Steur et al. (2009) found a summer minimum also in the East Greenland Current.

The exchanges through the Fram Strait have also been estimated from models, e.g., Karcher et al. (2003, 2008), Maslowski et al. (2004) and Fieg et al. (2010). The transports are similar or somewhat smaller than those obtained from direct current measurements and geostrophy. Fieg et al. (2010)

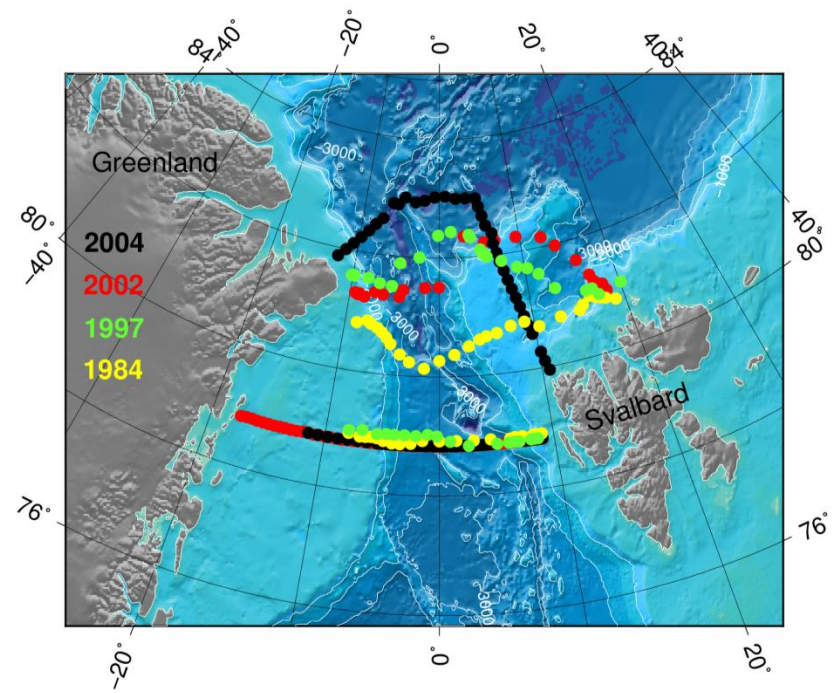

Fig. 2. Fram Strait bathymetry (IBCAO) with 1984, 1997, 2002 and 2004 stations. Map produced with GMT (Wessel and Smith, 1998).

find similar fluctuations as in the current metre array and no annual cycle in the net transport.

In this paper the exchanges of volume, heat and freshwater in the Fram Strait are estimated as well as the recirculation in the strait. The transports of volume, heat and freshwater through Fram Strait are obtained by computing the geostrophic transports through two CTD sections, one section located in Fram Strait at about $79^{\circ} \mathrm{N}$ and the second taken north of the strait extending from Svalbard to Greenland (Fig. 2). A set of conservation constraints are applied on volume, heat and salt for the boxes defined in the north and south by the CTD sections, to the east by the Svalbard slope and to the west by the Greenland slope. The undetermined reference velocities can then be estimated using a variational approach, without having to pre-define, for example, the net salt and volume transports in the deeper layers as was done in a previous study by Rudels et al. (2008).

Only few complete oceanographic sections have been occupied between Greenland and Svalbard north of Fram Strait beyond the recirculation area that can be combined with the $79^{\circ} \mathrm{N}$ section. (Figs. 2 and 3). The summers studied are 1984, 1997, 2002 (with one section taken in spring) and 2004. The exchanges of volume, heat and freshwater as well as the transports of different water masses are determined. The availability of two zonal (east-west) sections also makes it possible to estimate the summer ice melt in the Fram Strait as well as the local net heat loss in the area between the sections. The heat and freshwater transports are compared with atmospheric forcing to evaluate their credibility.

The recirculation in the Fram Strait is not fully understood. The zonal section pair computations are also used to separate the recirculation in the Fram Strait from the exchanges between the Arctic Ocean and the Nordic Seas. The 
1984 Potential Temperature $\left({ }^{\circ} \mathrm{C}\right)$
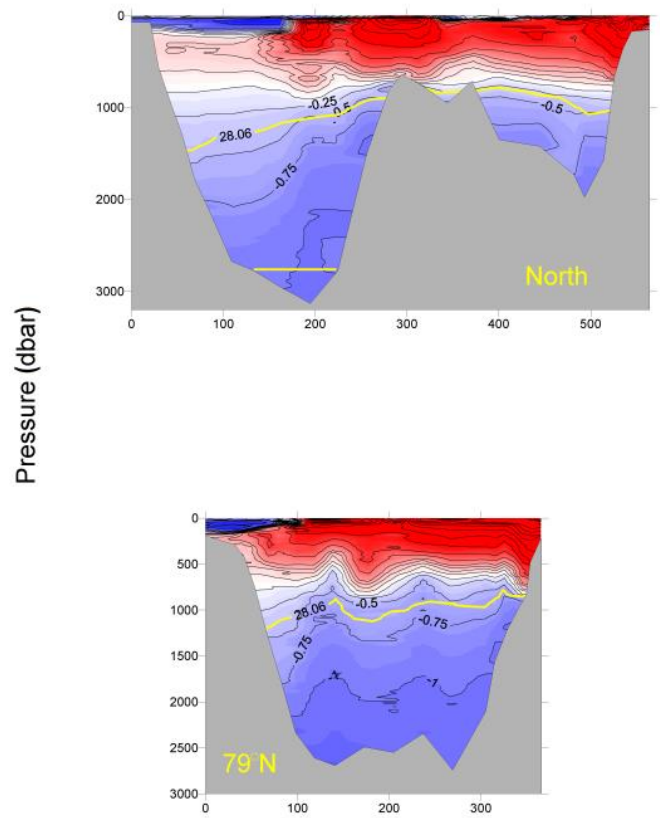

Distance $(\mathrm{km})$

2002 Potential Temperature $\left({ }^{\circ} \mathrm{C}\right)$

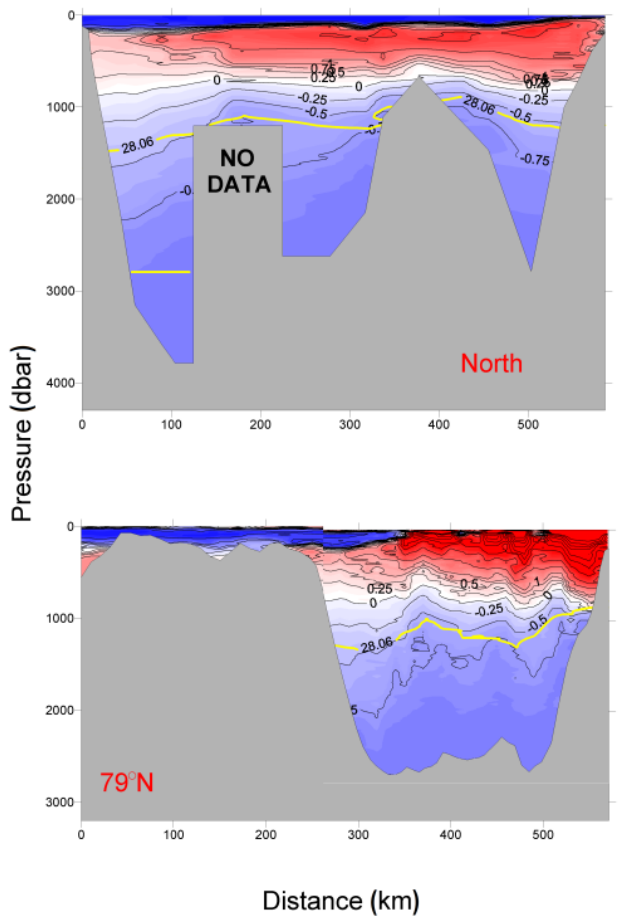

1997 Potential Temperature $\left({ }^{\circ} \mathrm{C}\right)$

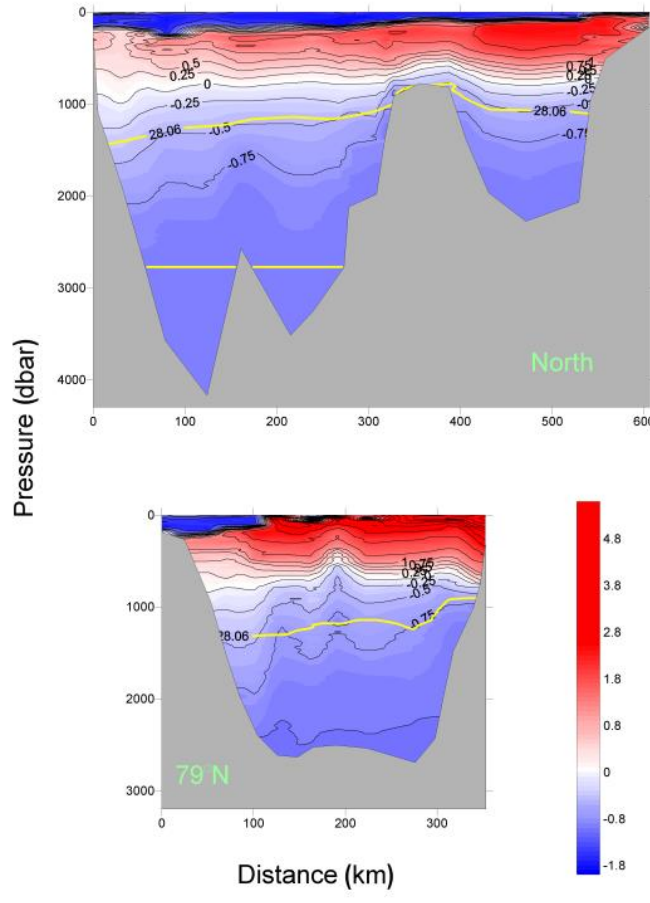

2004 Potential Temperature $\left({ }^{\circ} \mathrm{C}\right)$

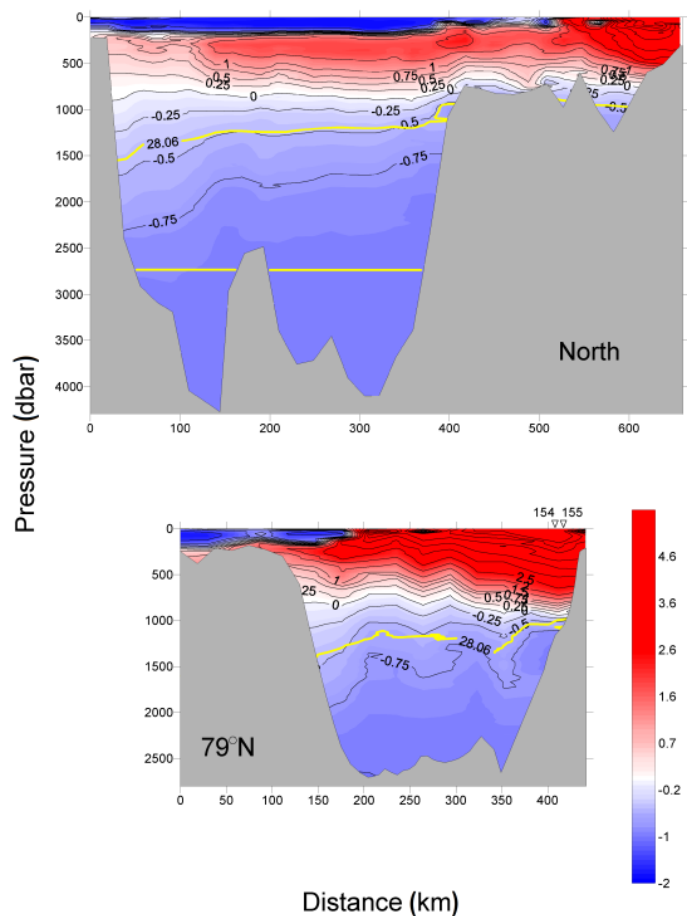

Fig. 3a. Caption on next page. 

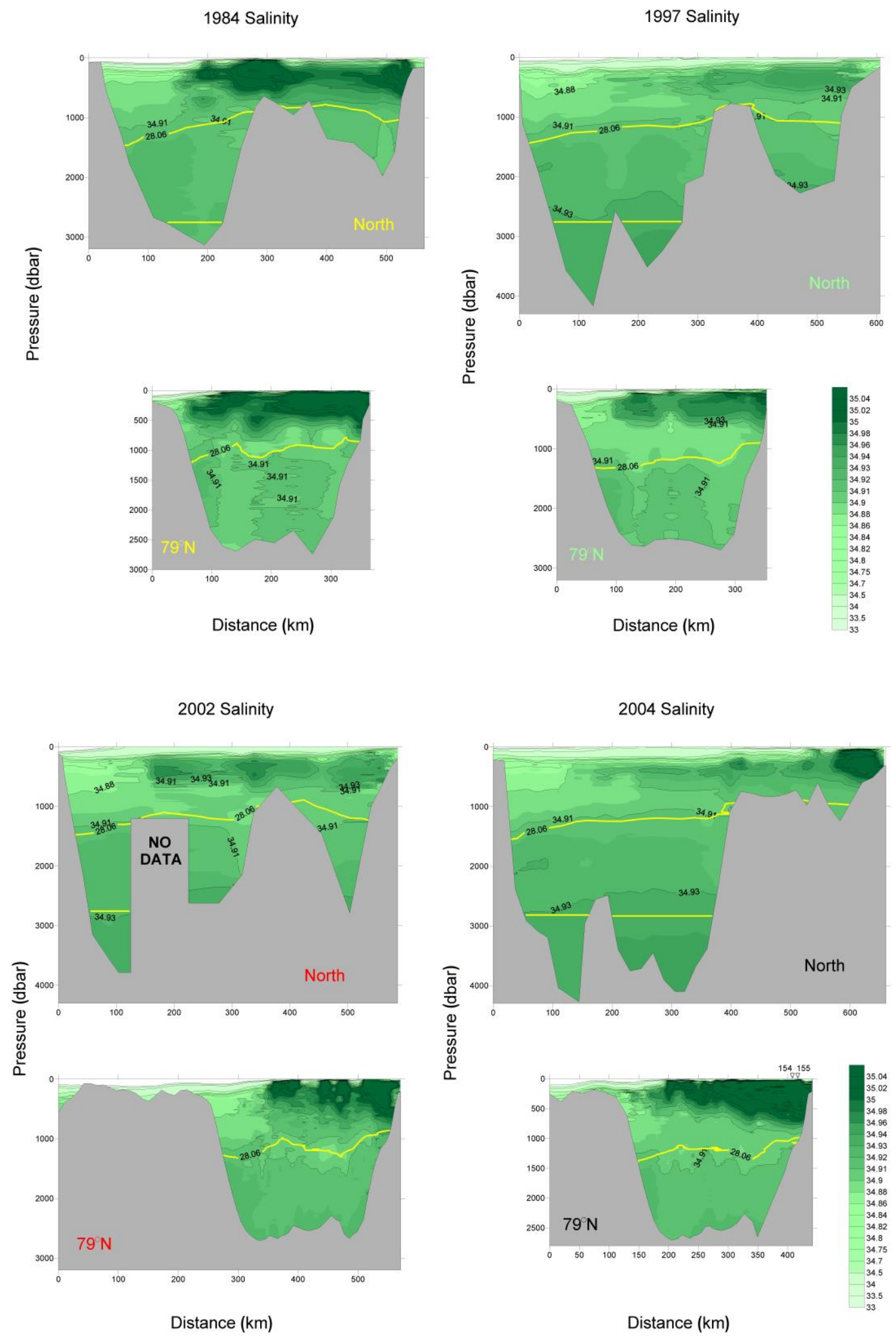

Fig. 3b. Caption on next page. 
1984 Velocity $(\mathrm{cm} / \mathrm{s})$
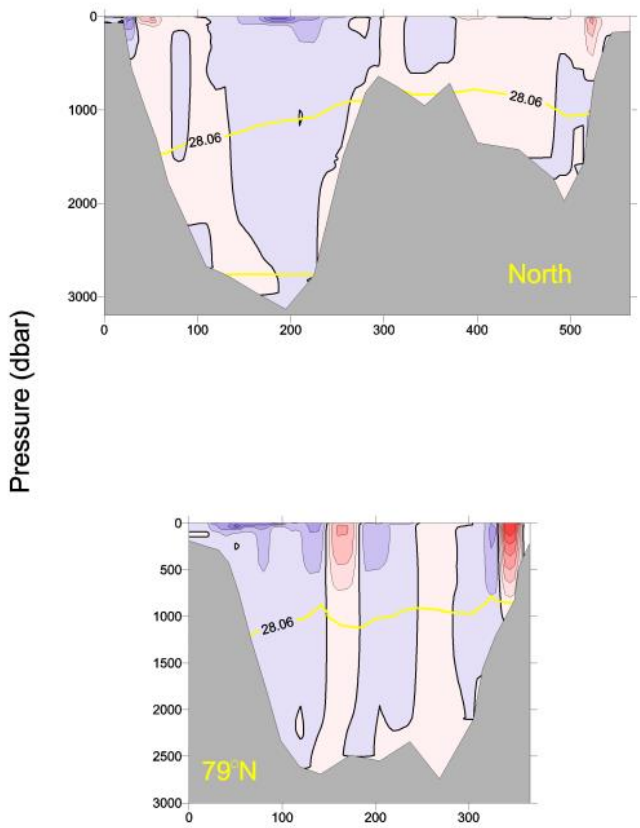

Distance $(\mathrm{km})$

2002 Velocity $(\mathrm{cm} / \mathrm{s})$

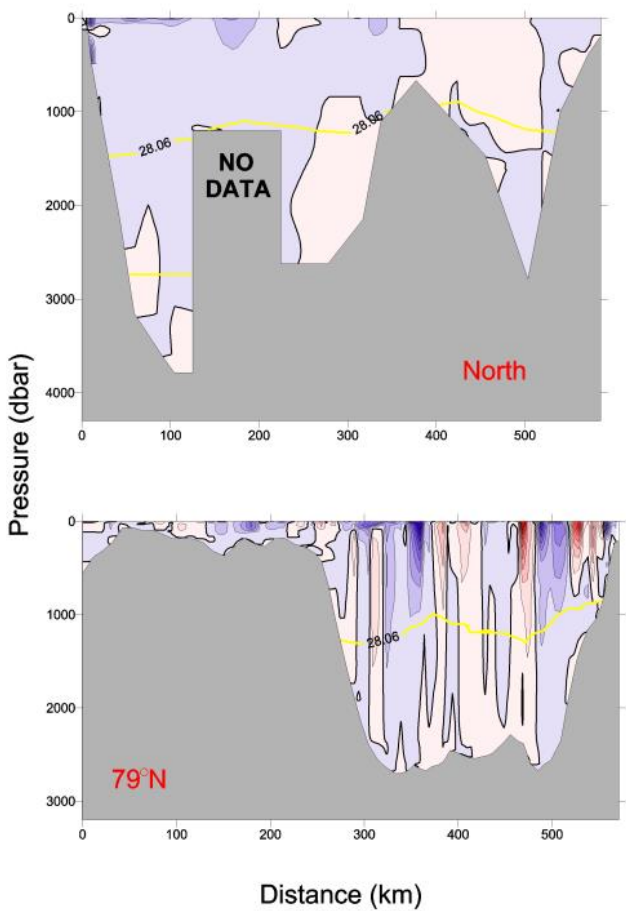

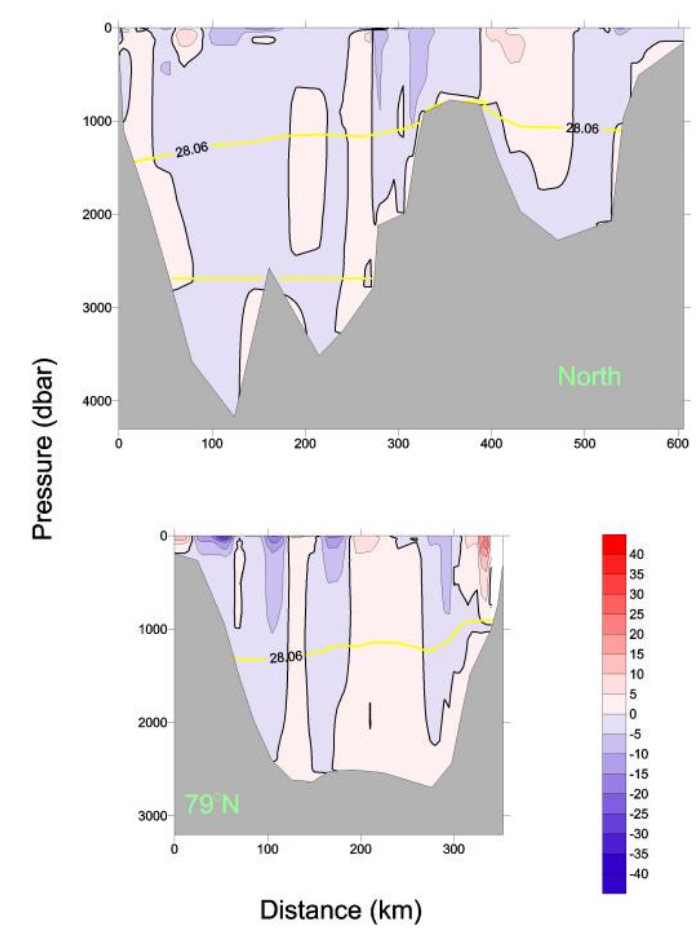

1997 Velocity $(\mathrm{cm} / \mathrm{s})$

2004 Velocity $(\mathrm{cm} / \mathrm{s})$

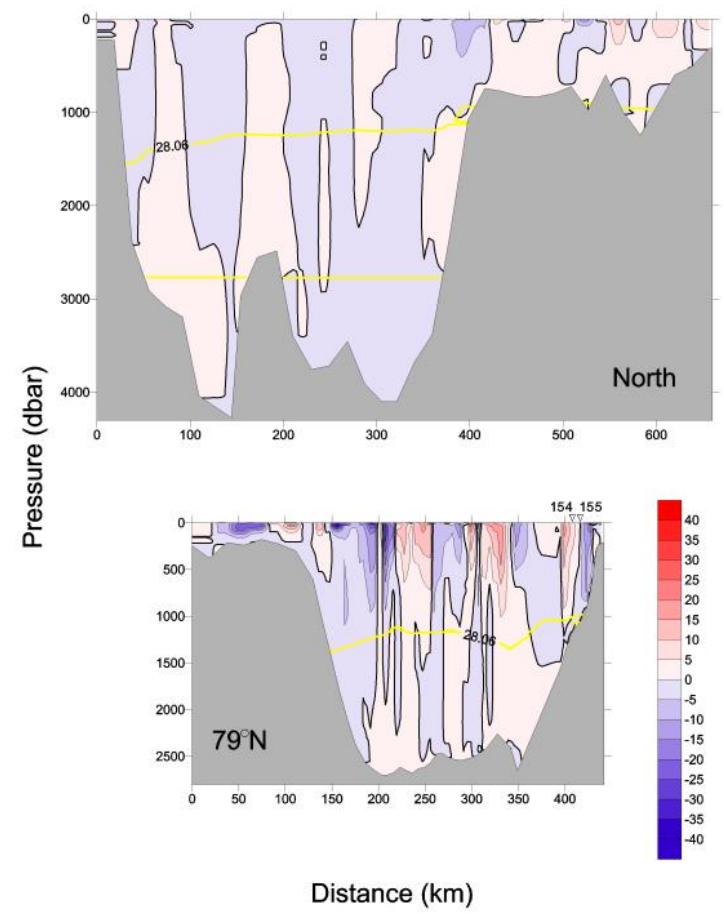

Fig. 3c. (a) Potential temperature, (b) salinity and (c) velocity with constraints applied from the zonal sections in 1984, 1997, 2002 and 2004 (Fig. 2). The constraint boundaries, potential density $\left(\sigma_{\theta}\right)$ surface 28.06 and the $2744 \mathrm{dbar}$ pressure level, are shown (yellow lines). Positive (negative) velocities are northward (southward). Stations 154 and 155 shown in Fig. 6 are marked with arrows in all the $200479^{\circ} \mathrm{N}$ sections. Colour coding of the sections (North for the northern section, and $79^{\circ} \mathrm{N}$ ) follows that of Fig. 2. 


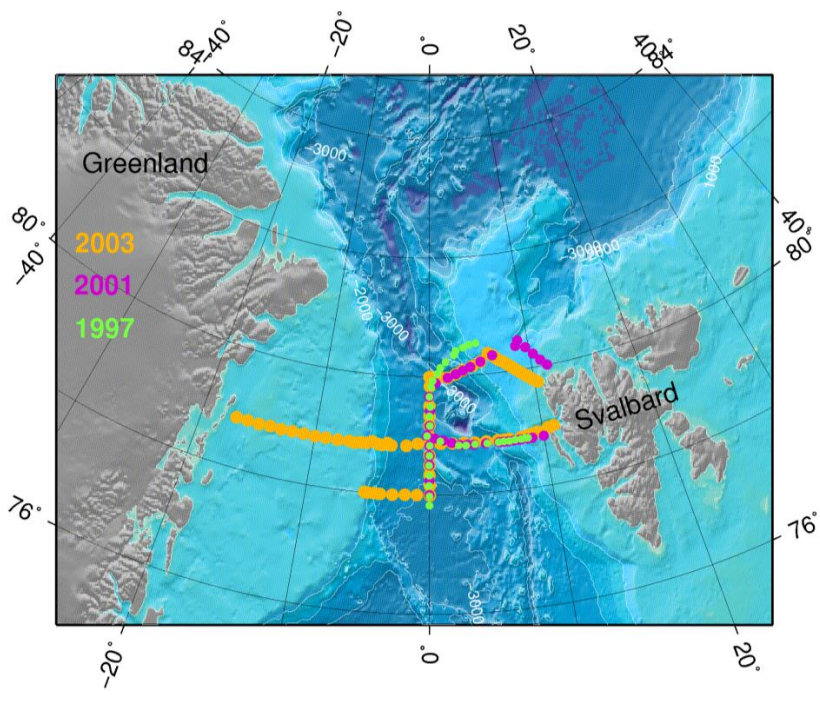

Fig. 4. Fram Strait bathymetry with 1997, 2001 and 2003 stations. Map produced with GMT (Wessel and Smith, 1998).

recirculation is computed more directly from north-south hydrographic sections located in the Fram Strait close to the Greenwich meridian $\left(0^{\circ}\right.$ longitude) between $78^{\circ} \mathrm{N}$ and $80^{\circ} \mathrm{N}$ (Figs. 4 and 5). The sections were taken in summers 1997, 2001 and 2003. Boxes closed by CTD sections on three sides and by the Greenland or Svalbard slope on one side are formed (Fig. 4) and geostrophic transports through the sides of the boxes are computed. The velocities are adjusted to fulfil volume, heat and salt conservation constraints.

In Sect. 2, the data are presented. In Sect. 3 the geostrophic transport computations, constraints and the variational method are described. In Sect. 4 results are shown for volume transports and recirculation as well as for heat (temperature) and freshwater transports. In Sect. 5 the transport estimates from different methods and the sources of error are discussed. Sect. 6 contains the discussion and conclusion.

\section{Data}

CTD (conductivity (salinity), temperature and depth) data obtained during various cruises (Figs. 2 and 4) are examined. The east-west section pairs (Fig. 2) used are two Lance 1984 (18 July to 29 August) sections, a VEINS (Variability of Exchanges In the Northern Seas) section pair taken in 1997 with a northern Polarstern section (2 to 27 July) combined with a Lance section at $79^{\circ} \mathrm{N}$ ( 25 August to 7 September) and two Polarstern 2004 (17 July to 26 August) sections taken during the ASOF (Arctic Subarctic Ocean Fluxes) programme. A two-part Oden section in the north taken in 2002 (9 to 14 May) was also used together with a Polarstern section at $79^{\circ} \mathrm{N}$ (31 July to 15 August). (Figs. 2 and 3). The north-south sections (Figs. 4 and 5) are from 1997 (24 Au-

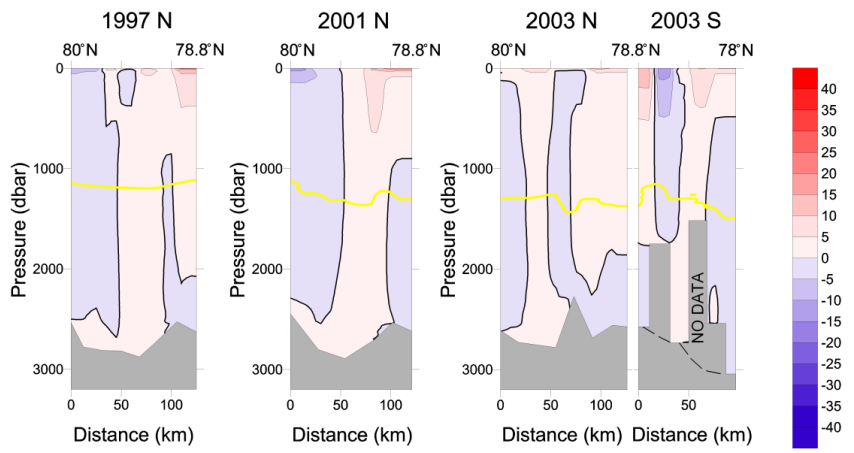

Fig. 5. Velocity with constraints applied from the meridional sections in 1997, 2001 and 2003 (Fig. 4) showing the constraint boundary, potential density $\left(\sigma_{\theta}\right)$ surface 28.06 (yellow lines). Positive (negative) velocities are westward (eastward).

gust to 15 September) and 2003 (8 to 23 September) taken by Lance, and 2001 by Polarstern (23 June to 27 July).

For all years the data have been averaged for every 1 dbar except for 1997 Lance where the average is over 2 dbar. The data were extrapolated to the surface $(0 \mathrm{dbar})$ by taking the values from the uppermost measurements and retaining these all the way to the surface. The instruments used were Seabird 911+ CTDs except in 1984 when a Neil Brown Mark III CTD was used. The CTD data, except in 1984, have been processed using the Seabird software and the conductivity has been calibrated against water samples. The salinity error is about 0.003 except for the 1997 Polarstern cruise, where it is 0.005 . The 1984 data had a drifting pressure sensor and the data had to be adjusted over time as well as calibrated against salinity samples. Unfortunately many of the calibration samples were destroyed as a geological sample was dropped on a salinity box. The error in salinity on the 1984 data could, therefore, be \pm 0.004 . The 1984 data have been processed by removing instabilities through homogenising the underlying layer to give static stability and the surface layer, 0 to $10 \mathrm{dbar}$, has been given the salinity and temperature values measured at $10 \mathrm{dbar}$.

Vessel mounted ADCP (Acoustic Doppler Current Profiler) data are available underway from the Polarstern 2004 cruise. The instrument is a narrow band $150 \mathrm{kHz}$ ADCP from RD Instruments. The ADCP pings have been averaged within $1 \mathrm{~min}$ ensembles and $8 \mathrm{~m}$ bins. The velocity data used here have been de-tided using the AOTIM-5 model by removing all semi-diurnal and quarter-diurnal tidal constituents (Padman and Erofeeva, 2004). The ADCP data were further averaged onto $10 \mathrm{~min}$ and $10 \mathrm{~m}$ cells and reach from $25 \mathrm{~m}$ to a maximum depth of $425 \mathrm{~m}$.

Era Interim Reanalyses, produced by the European Centre for Medium-Range Weather Forecasts (ECMWF) and publicly available at http://data-portal.ecmwf.int/, are used to compute surface meteorological fluxes for 1984, 1997, 2002 and 2004. The data used are $12 \mathrm{~h}$ cumulative values of surface 


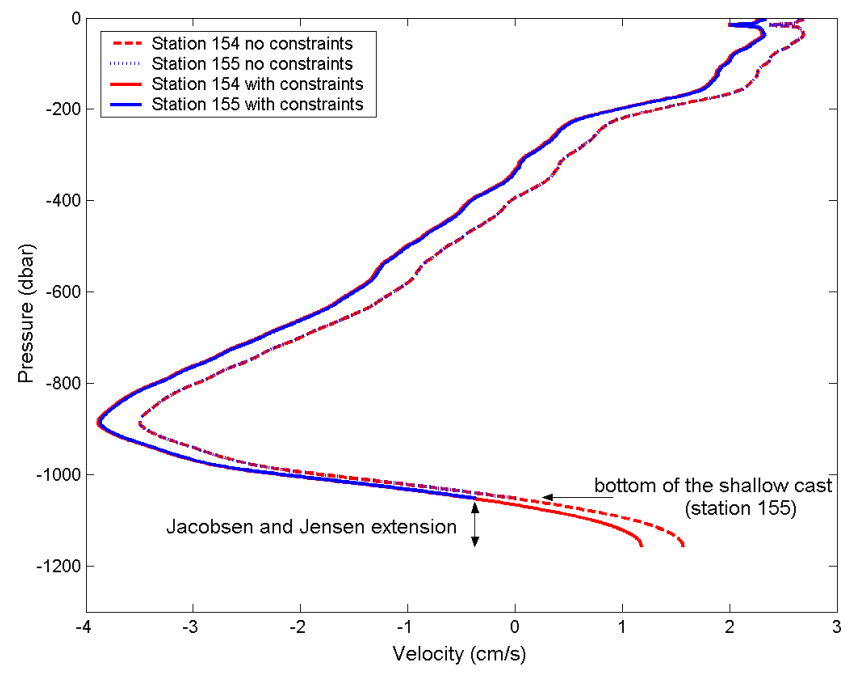

Fig. 6. Velocity profiles with (solid lines) and with no (dashed lines) constraints applied for two station halves between stations 154 and 155 in 2004 located on the Svalbard slope in the $79^{\circ} \mathrm{N}$ section (locations shown in Fig. 3). Velocity is first set to zero at the bottom of the shallow cast and method of Jacobsen and Jensen is used to estimate the velocity below this level for the deep station.

net solar and thermal radiation fluxes, surface latent and sensible heat fluxes, precipitation and evaporation, at the spatial resolution of $0.75^{\circ}$ (lat/lon). The wind fields in Fram Strait are also obtained from the ERA Interim Reanalyses.

Sea ice edge is visually located from the US National Snow and Ice Data Center's satellite based monthly sea ice concentration and extent images on Sea Ice Index (http://nsidc.org/data/seaice_index/) and also obtained from the ERA Interim Reanalyses.

\section{Method}

\subsection{Geostrophic computations}

The geostrophic method assumes a balance between the Coriolis force and the pressure gradient. The geostrophic velocities between station pairs are first computed with zero velocity at the bottom of the cast of the shallower station of the pair. The method of Jacobsen and Jensen (1926) is then used for determining the velocities at the deeper station at all levels located below the deepest common level of the station pair (Appendix A).

From direct current observations it is known that the currents in Fram Strait close to bottom tend to flow northward on the eastern slope and southward on the western slope. In the slope areas on all sections, the velocity is, therefore, set to zero either at the bottom of the cast of the shallow station or at the bottom of the cast of the deep station of the station pair (Fig. 6). The choice is made in order to have the flow in the deep part, below the maximum depth of the shallow station, going in the direction indicated by the direct current observations, that is northward in the east and southward in the west. For the stations in the central parts, on the shelf areas and in Sofia Deep the velocity is kept at zero at the bottom of the shallower station cast. Conservation constraints are then applied on volume, heat and salt.

\subsection{Determination of the barotropic velocity correction}

\subsubsection{Conservation constraints and the variational approach}

Conservation constraints are formulated on closed boxes in a way similar to Houssais et al. (1995). In general form they read (See Appendix B for details):

$\iint_{\gamma} v^{\mathrm{b}}(x) R(x, z) \mathrm{d} x \mathrm{~d} z+\iint_{\gamma} v^{\mathrm{bc}}(x, z) R(x, z) \mathrm{d} x \mathrm{~d} z=C=0$

where $\mathrm{v}^{\mathrm{b}}(x)$ is the depth-independent barotropic velocity, $\mathrm{v}^{\mathrm{bc}}(x, z)$ is the baroclinic velocity from the geostrophic computations, $R$ is either $S$ for salt transport, $\theta$ for heat transport or 1 for volume transport and $\gamma$ stands for the area of the CTD sections on which the constraint is applied. The constraints are deliberately kept weak with only heat, volume and salt, but not water masses conserved. This allows for both isopycnal and diapycnal mixing between water masses. The boxes are assumed to have no sources and sinks and the constraints $C$ become equal to zero.

A variational approach is then used to find the least energetic barotropic corrections needed to fulfil the constraints in a way similar to the method in Rudels et al. (2008). The barotropic velocity component $\mathrm{v}^{\mathrm{b}}$ is computed by minimising the kinetic energy of the barotropic part (not the total kinetic energy as in Rudels, 1987; Houssais et al.,1995) using the method of Lagrangian multipliers (Lanczos, 1970; Wunsch, 1978; Stommel and Veronis, 1981). The barotropic reference velocities are determined by solving the MoorePenrose inverse $\mathrm{B}\left(\mathrm{A}^{T} \mathrm{~B}\right)^{-1}$ with no error term introduced in the equations (See Appendix B for details).

\subsubsection{Zonal (east-west) sections}

Geostrophic transports are computed for the 1984, 1997, 2002 and 2004 east-west section pairs, where one section is located in Fram Strait at about $79^{\circ} \mathrm{N}$ and the second farther north, between $80^{\circ} \mathrm{N}$ and $83^{\circ} \mathrm{N}$ (Fig. 2). All water exchanged through Fram Strait is assumed to pass through the two sections and constraints can be formulated for the box enclosed by the sections and by Greenland and Svalbard. A maximum of 6 constraints are set on the transports through the CTD section sides of the boxes.

Constraint 1 is applied on the whole water column, $\gamma_{1}$, and requires that salt is conserved in the whole box. This allows for input and removal of freshwater at the sea surface, e.g., by ice melt or freezing. The salinity of sea ice is taken to be 
Table 1. Baroclinic volume transports (Sv) from zonal sections (no constraints applied) through the $79^{\circ} \mathrm{N}$ and the northern sections. Positive (negative) transports are northward (southward).

\begin{tabular}{lrrrrrr}
\hline & \multicolumn{2}{c}{$79^{\circ} \mathrm{N}$} & \multicolumn{3}{c}{ North } \\
\hline Year & Northward & Southward & Net & Northward & Southward & Net \\
\hline 1984 & 7.77 & -9.20 & $\mathbf{- 1 . 4 3}$ & 3.45 & -8.37 & $\mathbf{- 4 . 9 2}$ \\
1997 & 3.85 & -7.94 & $\mathbf{- 4 . 0 9}$ & 4.01 & -8.69 & $\mathbf{- 4 . 6 8}$ \\
2002 & 9.54 & -13.97 & $\mathbf{- 4 . 4 4}$ & 3.08 & -6.78 & $\mathbf{- 3 . 7 0}$ \\
2004 & 8.31 & -9.82 & $\mathbf{- 1 . 5 1}$ & 4.25 & -9.01 & $\mathbf{- 4 . 7 6}$ \\
mean & 7.37 & -10.23 & $\mathbf{- 2 . 8 6}$ & 3.70 & -8.21 & $\mathbf{- 4 . 5 2}$ \\
std & 2.13 & 2.26 & $\mathbf{1 . 4 0}$ & 0.46 & 0.86 & $\mathbf{0 . 4 8}$ \\
\hline
\end{tabular}

zero. The volume change caused by the melting or freezing sea ice is allowed to leave or enter the box. Mainly melting is expected during the summer observation period. Because of the air-sea-ice interactions heat is not conserved. Constraints 2-4 are applied on the part of the water column, $\gamma_{2}=\gamma_{3}=\gamma_{4}$, excluding Sofia Deep area, below and at the potential density $\left(\sigma_{\theta}\right)$ surface 28.06 and above the 2744 dbar pressure level. The upper boundary of this volume is assumed to be below the influence of the atmosphere and local convection. The isopycnal also intersects Yermak Plateau, thus, separating the Fram Strait proper from the Sofia Deep. The lower boundary is the bottom depth of the deepest station cast on the $79^{\circ} \mathrm{N}$ section. Constraint 2 requires volume, constraint 3 salt and constraint 4 heat to be conserved within the above described part of the water column. Constraint 5 is applied below and at the $2744 \mathrm{dbar}$ pressure level on the northern section, $\gamma_{5}$, and requires that volume is conserved below and at $2744 \mathrm{dbar}$, preventing any net transport in the northern section deeper than the $79^{\circ} \mathrm{N}$ section. Constraint 6 is applied below and at $750 \mathrm{dbar}$ in the Sofia Deep, $\gamma_{6}$, and requires that volume is conserved. The 750 dbar boundary is the approximate depth below which there is no direct exchange between the Sofia Deep and the Fram Strait proper because of the blocking effect of the Yermak Plateau. The 2004 Polarstern cruise does not cross Sofia Deep and constraint 6 is not required. For the other years all 6 constraints are required.

The 2002 Oden sections north of Fram Strait are combined and used together with a Polarstern section at $79^{\circ} \mathrm{N}$ taken two months later. A gap exists between the western and eastern Oden section and these sections were, therefore, treated separately in a previous transport estimate (Marnela et al., 2008) (Fig. 2). The eastern section was given zero velocity at the surface by them. Here the sections are combined and the initial velocity is set to zero near the bottom (see above). An additional problem here is that the first two stations west of the gap only reach $1200 \mathrm{~m}$ (Fig. 3), which compromises the conservation constraints.

\section{Results}

\subsection{Volume transports and recirculation}

\subsubsection{Transports from zonal section pairs}

The net volume transports through the Fram Strait computed from the baroclinic velocities obtained from the hydrographic sections (Fig. 3a, b) with velocity set to zero near the bottom and with no constraints applied are estimated as $4.5 \mathrm{~Sv}$ southward through the northern section and $2.9 \mathrm{~Sv}$ southward through the $79^{\circ} \mathrm{N}$ section averaged over the four east-west sections (Table 1).

The net volume transport through Fram Strait with the constraints applied is estimated as $3.1 \mathrm{~Sv}$ southward averaged over the four northern and four $79^{\circ} \mathrm{N}$ sections. The transports are about $2 \mathrm{~Sv}$ for 1984 and 2004, and $4 \mathrm{~Sv}$ for 1997 and 2002 (Table 2). The mean total northward flow at $79^{\circ} \mathrm{N}$ is about $8 \mathrm{~Sv}$, and at the northern section $5 \mathrm{~Sv}$. The southward flow is $11 \mathrm{~Sv}$ at $79^{\circ} \mathrm{N}$ and $8 \mathrm{~Sv}$ at the northern section (Fig. 7, Table 2).

The transports of different water masses are also computed. Here we use the simplified water mass classification with six water masses introduced by Rudels et al. (2008). The water masses are separated by isopycnals except in the intermediate layer where both the dense Atlantic Water (dAW) and the Intermediate Water (IW) occupy the same density interval, but are separated by the $0{ }^{\circ} \mathrm{C}$ isotherm (Fig. 8). The fluxes of the different waters are shown in Fig. 8 in $\theta \mathrm{S}$ diagrams.

The main net southward transports occur in the surface layer, where the low salinity cold Polar water is exported, and in the intermediate density range (dAW and IW), where the net outflow is close to $2 \mathrm{~Sv}$ in all years. This is in agreement with Rudels et al. (2008). These two outflows reflect, in the upper part, the river runoff and net precipitation, and the input of freshwater and low salinity Pacific water to the Arctic Ocean, and in the lower part, the water entering the Arctic Ocean over the Barents Sea.

The differences in water mass properties between the sections as well as between northward and southward flow 
Table 2. Transports from zonal sections through the $79^{\circ} \mathrm{N}$ and the northern sections with constraints applied. Positive (negative) net transports are northward (southward). (a) Volume transports (Sv), (b) Heat/temperature transports (TW) relative to a varying reference temperature. Note that northward (southward) transports are negative (positive) when the transport has temperature $<$ reference temperature (c) Freshwater transports $(\mathrm{mSv})$ relative to a varying reference salinity. Northward (southward) transports are negative (positive) when the transport has salinity $<$ reference salinity.

\begin{tabular}{|c|c|c|c|c|c|c|c|}
\hline \multirow[b]{2}{*}{ Year } & & \multicolumn{3}{|c|}{$79^{\circ} \mathrm{N}$} & \multicolumn{3}{|c|}{ North } \\
\hline & & Northward & Southward & Net & Northward & Southward & Net \\
\hline \multicolumn{8}{|l|}{ (a) } \\
\hline 1984 & & 7.83 & -10.00 & -2.17 & 5.22 & -7.36 & -2.14 \\
\hline 1997 & & 4.12 & -8.37 & -4.25 & 4.14 & -8.38 & -4.24 \\
\hline 2002 & & 9.89 & -14.01 & -4.13 & 3.03 & -7.10 & -4.07 \\
\hline 2004 & & 8.66 & -10.48 & -1.82 & 6.05 & -7.81 & -1.76 \\
\hline mean & & 7.62 & -10.72 & -3.09 & 4.60 & -7.66 & -3.05 \\
\hline std & & 2.15 & 2.06 & 1.10 & 1.14 & 0.49 & 1.11 \\
\hline Year & $\operatorname{Ref} T$ & Northward & Southward & Net & Northward & Southward & Net \\
\hline \multicolumn{8}{|l|}{ (b) } \\
\hline 1984 & 1.141 & 34.2 & 8.8 & 43.1 & -3.6 & 21.9 & 18.3 \\
\hline 1997 & 0.389 & 16.6 & -2.0 & 14.7 & -4.2 & 14.3 & 10.1 \\
\hline 2002 & 0.817 & 33.8 & 1.9 & 35.7 & -5.2 & 26.6 & 21.3 \\
\hline 2004 & 1.089 & 33.1 & -5.0 & 28.1 & -6.2 & 31.9 & 25.7 \\
\hline mean & 0.861 & 29.4 & 0.9 & 30.4 & -4.8 & 23.7 & 18.9 \\
\hline std & 0.294 & 7.4 & 5.2 & 10.5 & 1.0 & 6.4 & 5.7 \\
\hline Year & $\operatorname{Ref} S$ & Northward & Southward & Net & Northward & Southward & Net \\
\hline \multicolumn{8}{|l|}{ (c) } \\
\hline 1984 & 34.756 & -53.4 & -8.1 & -61.6 & 10.6 & -34.7 & -24.2 \\
\hline 1997 & 34.650 & -10.7 & -8.4 & -19.0 & -4.5 & -6.5 & -11.0 \\
\hline 2002 & 34.672 & -34.6 & -44.5 & -79.1 & -15.5 & -5.3 & -20.7 \\
\hline 2004 & 34.752 & -24.8 & -42.0 & -66.7 & -11.6 & 5.6 & -6.0 \\
\hline mean & 34.710 & -30.9 & -25.7 & -56.6 & -5.2 & -10.2 & -15.5 \\
\hline std & 0.045 & 15.6 & 17.5 & 22.6 & 9.9 & 14.9 & 7.3 \\
\hline
\end{tabular}

through a section show that waters in the upper part, surface water and Atlantic water (AW), coming from the south, become colder between the two sections. AW also becomes less saline, whereas surface water only becomes less saline in 1984 and 1997, and more saline in 2002 and 2004 (Fig. 8).

At the upper levels the waters from the north become warmer between the northern and southern sections, but while the surface water becomes less saline, except in 1984, reflecting ice melt between the sections, the Arctic Atlantic Water (AAW) becomes more saline indicating mixing with recirculating AW.

At the deeper levels the intermediate (below $0{ }^{\circ} \mathrm{C}$ ) and deep waters from the north (blue spots in Fig. 8c, top panel) are warmer and more saline than the corresponding waters from the south (red spots in Fig. 8c) and in general the waters from the north become colder and less saline and the waters from the south warmer and more saline, except in 2002 the opposite, as they pass through the strait (Fig. 8c). The deep and intermediate waters at the $79^{\circ} \mathrm{N}$ section have become warmer and more saline in the 2000s.

\subsubsection{Volume transports from vessel mounted ADCP data}

Vessel mounted ADCP data are available from the Polarstern 2004 cruise. The largest ADCP velocities from the 2004 cruise are found at the $78.8^{\circ} \mathrm{N}$ section. On the $78.8^{\circ} \mathrm{N}$ section there are rather regular fluctuations in the direction, on the eastern side of the strait south-westward and northwestward and on the western side mainly south to southwestward. On both the northern and the $78.8^{\circ} \mathrm{N}$ section, northward transports are mainly confined to the eastern side of the sections (West Spitsbergen Current) and southward flow can be seen on the western side (East Greenland Current), but also as fluctuations along the $79^{\circ} \mathrm{N}$ section. In the northern section the strongest northward flow is seen 
Table 3. 2004 volume transports of a surface layer at 35 to $425 \mathrm{~m}$ depth divided to about $5^{\circ}$ sections from ADCP velocities taken at every $0.25^{\circ}$ and from geostrophy with constraints applied. Transports are positive northward and negative southward.

\begin{tabular}{|c|c|c|c|c|c|c|c|c|c|c|c|c|}
\hline \multirow{2}{*}{$\begin{array}{l}\text { Longitude } \\
\text { range }\left[{ }^{\circ}\right]\end{array}$} & \multicolumn{2}{|c|}{$-12^{\circ} \ldots-10^{\circ}$} & \multicolumn{2}{|c|}{$-10^{\circ} \ldots-5^{\circ}$} & \multicolumn{2}{|c|}{$-5^{\circ} \ldots 0^{\circ}$} & \multicolumn{2}{|c|}{$0^{\circ} \ldots 5^{\circ}$} & \multicolumn{2}{|c|}{$5^{\circ} \ldots 10^{\circ}$} & \multicolumn{2}{|c|}{$10^{\circ} \ldots 12^{\circ}$} \\
\hline & $\mathrm{ADCP}$ & geostr & $\mathrm{ADCP}$ & geostr & $\mathrm{ADCP}$ & geostr & $\mathrm{ADCP}$ & geostr & $\mathrm{ADCP}$ & geostr & $\mathrm{ADCP}$ & geostr \\
\hline $\begin{array}{l}\text { North } \\
\text { Northward }\end{array}$ & 0.01 & 0.11 & 0.25 & 0.14 & 0.15 & 0.15 & 0.32 & 0.13 & 0.51 & 1.27 & 0.09 & 0.56 \\
\hline $\begin{array}{l}\text { North } \\
\text { Southward }\end{array}$ & -0.37 & -0.11 & -0.69 & -0.41 & -0.26 & -0.15 & -0.12 & -0.16 & -0.48 & -1.44 & -0.07 & -0.04 \\
\hline North Net & -0.36 & -0.01 & -0.44 & -0.28 & -0.11 & -0.01 & 0.21 & -0.03 & 0.03 & -0.17 & 0.02 & 0.52 \\
\hline $\begin{array}{l}79^{\circ} \mathrm{N} \\
\text { Northward }\end{array}$ & 0.13 & 0.05 & 0.27 & 0.32 & 1.24 & 1.07 & 2.35 & 2.14 & 1.46 & 0.63 & - & - \\
\hline $\begin{array}{l}79^{\circ} \mathrm{N} \\
\text { Southward }\end{array}$ & -0.22 & -0.07 & -1.14 & -0.73 & -2.48 & -2.01 & -2.38 & -1.17 & -0.89 & -0.54 & - & - \\
\hline $79^{\circ} \mathrm{N}$ Net & -0.09 & -0.02 & -0.86 & -0.41 & -1.24 & -0.93 & -0.03 & 0.97 & 0.57 & 0.09 & - & - \\
\hline
\end{tabular}
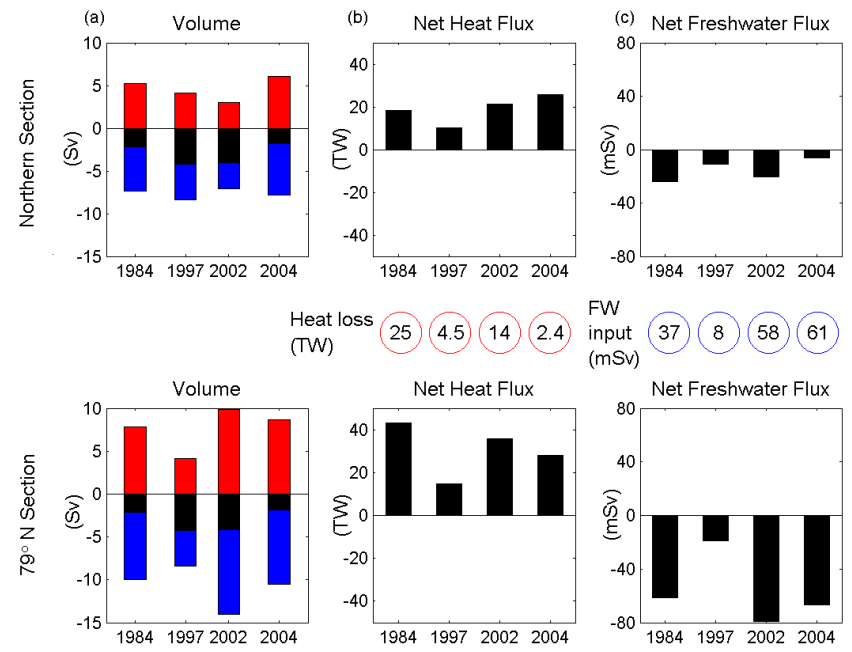

Fig. 7. Transports of (a) volume (red northward, blue southward, black net) of the whole water column and (b) the net heat and (c) net freshwater fluxes relative to the mean temperature and salinity of the total transports through the two sections in each year. The heat loss and freshwater input between the sections are shown with numbers in the centre.

just north of Svalbard and on the western flanks of Yermak Plateau, at about $82^{\circ} \mathrm{N}, 7^{\circ}$ E. (Fig. 9).

The ADCP data are used for comparison with the velocities determined by geostrophy. The ADCP data for the computations are selected corresponding to the centre points of where the geostrophic velocities with constraints applied are thought to be valid, i.e., between two neighbouring CTD stations at $1 / 4$ and $3 / 4$ of the in-between distance. ADCP velocities are averaged over an area within $\pm 0.1^{\circ}$ in longitude and $\pm 0.02^{\circ}$ in latitude to these points. Both the ADCP and geostrophic velocities are averaged over a $35-55 \mathrm{~m}$ layer representing the surface water and over a $155-255 \mathrm{~m}$ layer representing the AW layer. The differences between the depth- averaged geostrophic velocity and the ADCP velocity component normal to the line connecting the CTD stations in the surface layer and AW layer are then added to the geostrophic velocities of the corresponding water masses to obtain an ADCP referenced velocity (see water mass definitions in Fig. 8a, b). The correlation between the ADCP mean velocities and geostrophic mean velocities at the $79^{\circ} \mathrm{N}$ section is 0.75 for surface water layer and 0.63 for AW layer, but in the northern section there is no correlation for either water mass.

The results from the ADCP referenced geostrophy give net southward transports of both surface water and AW through both sections. The net surface water volume flow is $1.5 \mathrm{~Sv}$ southward through the $79^{\circ} \mathrm{N}$ section and $1.2 \mathrm{~Sv}$ through the northern section. The net AW volume flow is $1.8 \mathrm{~Sv}$ southward through the $79^{\circ} \mathrm{N}$ section and $1.6 \mathrm{~Sv}$ southward through the northern section. A gap in the stations at the $79^{\circ} \mathrm{N} \mathrm{sec}-$ tion at about $5^{\circ} \mathrm{E}$ misses a substantial part in the geostrophy of the southward flow visible in the ADCP measurements (Fig. 9).

The ADCP transports are also computed for a 35 to $425 \mathrm{~m}$ layer, where ADCP mean is taken every $0.25^{\circ}$. At $79^{\circ} \mathrm{N}$ $5.5 \mathrm{~Sv}$ is found to flow northward and 7.1 Sv southward (net 1.6 Sv southward). Divided between western and eastern parts of the strait, to the west of the $0^{\circ}$ meridian the transports are $1.6 \mathrm{~Sv}$ northward and $3.8 \mathrm{~Sv}$ southward, and to the east 3.8 Sv northward and 3.3 Sv southward. Through the northern section the transports are $1.3 \mathrm{~Sv}$ northward and $2.0 \mathrm{~Sv}$ southward (net $0.7 \mathrm{~Sv}$ southward) (Table 3).

From geostrophy the transports for a 35 to $425 \mathrm{~m}$ layer at $79^{\circ} \mathrm{N}$ are $4.2 \mathrm{~Sv}$ northward and $4.5 \mathrm{~Sv}$ southward. West of $0^{\circ} \mathrm{E}$ the transports are $1.5 \mathrm{~Sv}$ northward and $2.8 \mathrm{~Sv}$ southward, and east of $0^{\circ} \mathrm{E} 2.8 \mathrm{~Sv}$ northward and $1.7 \mathrm{~Sv}$ southward. Through the northern section the net transport is $0 \mathrm{~Sv}$ with $2.3 \mathrm{~Sv}$ both northward and southward (Table 3 ). 

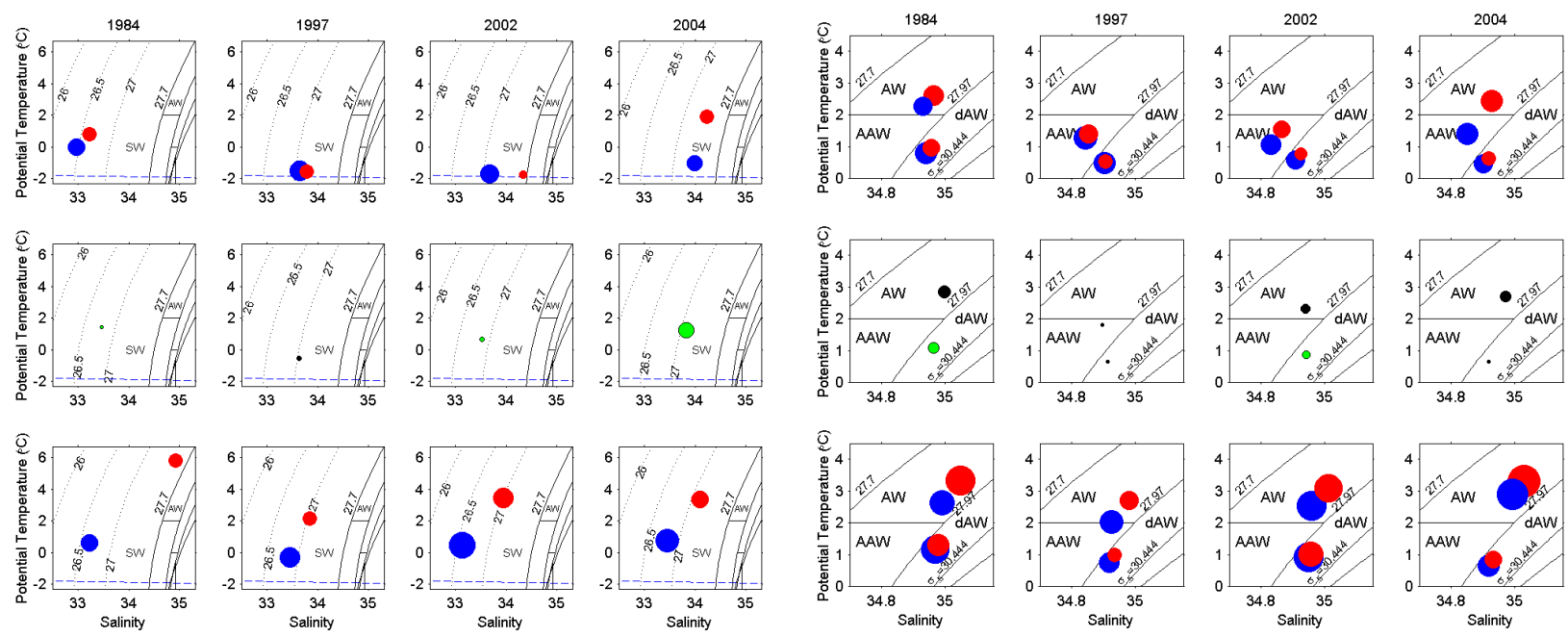

(a)

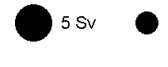

(b)

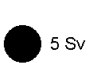

$2 \mathrm{sv} \bullet \mathrm{sv}$

$\bullet 0.5 \mathrm{~Sv} \quad \cdot 0.2 \mathrm{~Sv} \quad \cdot 0.1 \mathrm{sv}$
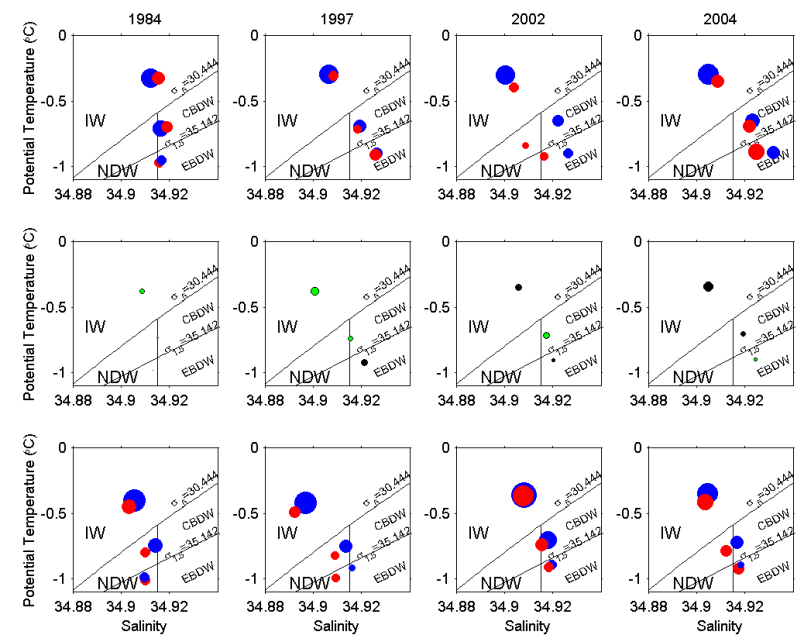

(c)

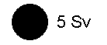

$2 \mathrm{~Sv}$

- $0.5 \mathrm{~Sv} \quad-0.2 \mathrm{~Sv}$

- $0.1 \mathrm{~Sv}$

Fig. 8. $\theta \mathrm{S}$ volume diagrams with mean potential temperatures and salinities for different water masses for each year. The mean potential temperatures and salinities of the transports are given by the positions of the circles and the volume transports by the size of the circles. Northward transports are red and southward blue. Northern section is shown in the top panel, the divergence (green) or convergence (black) of each water mass in the centre and the $79^{\circ} \mathrm{N}$ section in the bottom panel. The water masses used in the computations are (a) surface water SW $\left(\sigma_{\theta}<27.70\right)$, (b) $\mathrm{AW}\left(27.70 \leq \sigma_{\theta}<27.97\right.$, here further separated by $0{ }^{\circ} \mathrm{C}$ isotherm into AW and AAW) and dAW $\left(\sigma_{\theta} \geq 27.97, \sigma_{0.5}<30.444\right.$, $\theta>0{ }^{\circ} \mathrm{C}$ ), (c) intermediate water (IW) (separated by $0{ }^{\circ} \mathrm{C}$ isotherm from dAW) and deep waters (DWI $\left(\sigma_{0.5} \geq 30.444, \sigma_{1.5}<35.142\right)$ and DWII $\left.\left(\sigma_{1.5} \geq 35.142\right)\right)$. Limits are shown for NDW $=$ Nordic Seas Deep Water, CBDW $=$ Canadian Basin Deep Water and EBDW $=$ Eurasian Basin Deep Water.

\subsubsection{Recirculation from zonal sections}

An estimate for the recirculation can be obtained from the zonal sections. Here it is defined as northward transport through $79^{\circ} \mathrm{N}$ section minus northward transport through the northern section. In $19842.6 \mathrm{~Sv}$ is estimated to recirculate in the strait, in 1997 no recirculation is found, in 2002 6.9 Sv and in $20042.6 \mathrm{~Sv}$ (Table 2). The recirculation in the strait is larger than the net southward volume transport, ex- cept in 1997, and about $25 \%$ of the water flowing southward through $79^{\circ} \mathrm{N}$ is estimated to be recirculating water returning to the south.

The amount of AW recirculating is about $2 \mathrm{~Sv}$ except in 1997 close to zero (Fig. 8b). Of the AW entering the strait from the south almost $50 \%$ recirculates. The recirculating surface and Atlantic waters become colder and less saline (Fig. 8). The deepest water mass recirculates towards north by $0.5 \mathrm{~Sv}$ in 1997 and 2004 (southward flow through the 
Table 4. Volume transports (Sv) (positive westward) from the meridional sections with no constraints applied.

\begin{tabular}{rrrrrrr}
\hline & \multicolumn{2}{c}{$78^{\circ}-78.8^{\circ} \mathrm{N}$} & \multicolumn{3}{r}{$78.8^{\circ}-80^{\circ} \mathrm{N}$} \\
\hline Year & Westward & Eastward & Net & Westward & Eastward & Net \\
\hline 1997 & 2.56 & -1.87 & $\mathbf{0 . 6 9}$ & 1.80 & -1.14 & $\mathbf{0 . 6 6}$ \\
2001 & 2.31 & -1.34 & $\mathbf{0 . 9 7}$ & 2.10 & -2.67 & $-\mathbf{0 . 5 7}$ \\
2003 & 2.61 & -1.55 & $\mathbf{1 . 0 6}$ & 1.89 & -0.65 & $\mathbf{1 . 2 3}$ \\
\hline
\end{tabular}

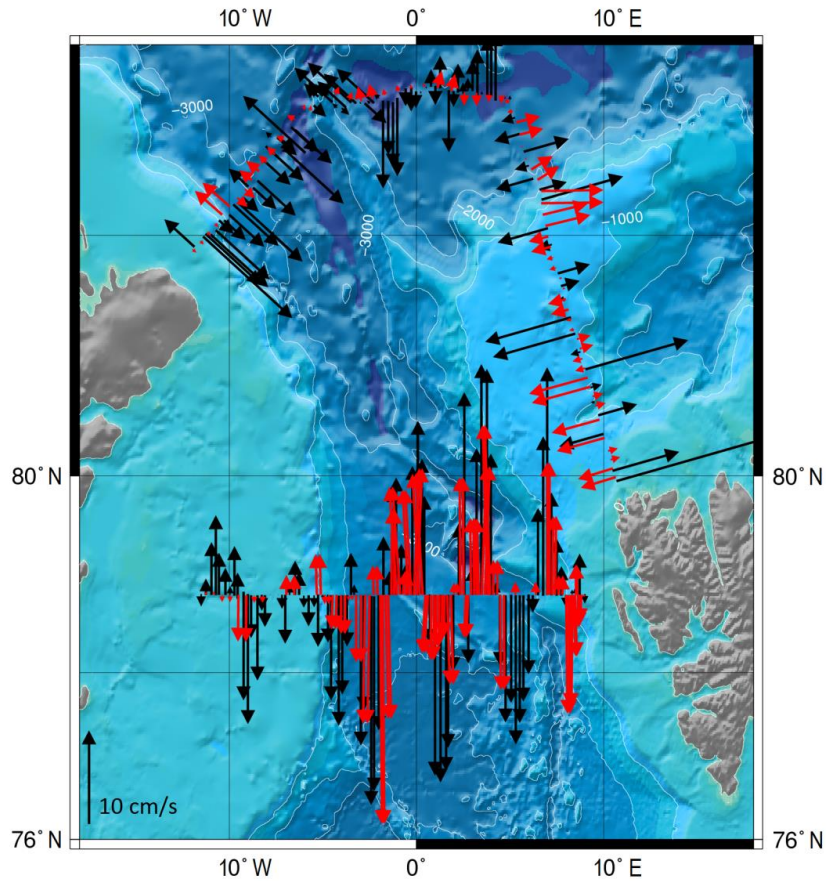

Fig. 9. Velocity vectors at approximately $160 \mathrm{~m}$ depth from geostrophy with constraints applied (red) and from vessel mounted ADCP at $0.25^{\circ}$ intervals (black) with only the velocity component approximately normal to the hydrography sections (northern section is divided into 3 subsections for averaging the directions) shown. Map produced with GMT (Wessel and Smith, 1998).

northern section minus southward flow through the $79^{\circ} \mathrm{N}$ section; Fig. 8c).

\subsubsection{Meridional (north-south) sections and recirculation}

Geostrophic transports are computed for the 1997, 2001 and 2003 north-south sections in Fram strait at $0^{\circ}$ longitude between $78^{\circ} \mathrm{N}$ and $80^{\circ} \mathrm{N}$ to get a better estimate of the recirculation in Fram Strait. The transports through a northsouth section extending from $78^{\circ} \mathrm{N}$ to $80^{\circ} \mathrm{N}$ are computed with velocity set to zero near the bottom and with no constraints applied (Table 4). The transport for 2003 is estimated as $2.3 \mathrm{~Sv}$ westward, for $20010.4 \mathrm{~Sv}$ westward and for 1997 1.2 Sv westward. The volume transports in 2003 and 1997 are divided almost equally between the $78^{\circ} \mathrm{N}$ to $78.8^{\circ} \mathrm{N}$ and
Table 5. Volume transports (Sv) (positive westward) from the meridional (north-south) sections with constraints applied.

\begin{tabular}{lrrrr}
\hline Year & 1997 & 2001 & \multicolumn{2}{c}{2003} \\
\hline Latitude & $78.8^{\circ}-80^{\circ} \mathrm{N}$ & $78.8^{\circ}-80^{\circ} \mathrm{N}$ & $78^{\circ}-78.8^{\circ} \mathrm{N}$ & $78.8^{\circ}-80^{\circ} \mathrm{N}$ \\
Surface water & 0.14 & -0.00 & 0.11 & 0.29 \\
AW & 0.37 & 0.06 & 0.70 & 0.50 \\
Dense AW & 0.19 & -0.02 & 0.41 & 0.28 \\
Intermediate water & 0.04 & -0.19 & -0.03 & 0.08 \\
Deep water I & -0.02 & -0.07 & -0.01 & -0.04 \\
Deep water II & 0.02 & 0.05 & 0.02 & -0.02 \\
Net & $\mathbf{0 . 7 4}$ & $\mathbf{- 0 . 1 7}$ & $\mathbf{1 . 2 0}$ & $\mathbf{1 . 0 9}$ \\
\hline
\end{tabular}

$78.8^{\circ} \mathrm{N}$ to $80^{\circ} \mathrm{N}$ sections. The transport for 2001 is $1.0 \mathrm{~Sv}$ westward between $78^{\circ} \mathrm{N}$ and $78.8^{\circ} \mathrm{N}$ and $0.6 \mathrm{~Sv}$ eastward between $78.8^{\circ} \mathrm{N}$ and $80^{\circ} \mathrm{N}$ (Table 4).

Two boxes can be formed in 2003 (Fig. 4) and conservation constraints applied on volume, heat and salt. The northern box is closed by the Svalbard slope in the east and by three CTD sections, one in the west along $0^{\circ}$-meridian and the others along $78.8^{\circ} \mathrm{N}$ and along about $80^{\circ} \mathrm{N}$. The southern box is closed by the Greenland slope in the west and by three CTD sections, one in the east along $0^{\circ}$-meridian and the others along $78^{\circ} \mathrm{N}$ and $78.8^{\circ} \mathrm{N}$.

Three constraints, 2 to 4 , are applied for the deep part below potential density 28.06 , allowing no volume, salt or heat to accumulate in the deep part (Eq. B1). The shallower stations on the slopes are less dense than 28.06 and the constraints are not applied to them nor are the stations included in the minimisation. For the computation of the recirculation across the $0^{\circ}$ longitude this should give a reasonable estimate since all the stations along $0^{\circ}$-meridian are deep. Two of the 2003 station casts in the along- $0^{\circ}$-meridian part of the southern box, however, miss a substantial amount of the water column near the bottom (Fig. 5).

The westward recirculation between $78^{\circ} \mathrm{N}$ and $80^{\circ} \mathrm{N}$ in 2003 with the constraints applied is estimated from the meridional sections as $2.3 \mathrm{~Sv}$. The transport of recirculating AW is $1.2 \mathrm{~Sv}$ and of dAW $0.7 \mathrm{~Sv}$, with slightly larger westward transport between $78-78.8^{\circ} \mathrm{N}$ than between $78.8-80^{\circ} \mathrm{N}$, (Table 5).

In 1997 and 2001 it is not possible to form both a northern and a southern box covering the $0^{\circ}$-meridian from $78^{\circ} \mathrm{N}$ to $80^{\circ} \mathrm{N}$, but only the northern box whose western section reaches from $78.8^{\circ} \mathrm{N}$ to $80^{\circ} \mathrm{N}$. In 1997 , the net transport between $78.8^{\circ} \mathrm{N}$ and $80^{\circ} \mathrm{N}$ is $0.7 \mathrm{~Sv}$ westward and in 2001 $0.2 \mathrm{~Sv}$ eastward. The transports of AW are westward in both years, but that of dAW is eastward in 2001 (Table 5).

\subsection{Heat and freshwater transports}

\subsubsection{Reference temperature and salinity}

The choice of reference temperature and salinity used to estimate the heat and freshwater transport is largely arbitrary and will affect the heat and freshwater flux estimates between the 
Nordic Seas and the Arctic Ocean, since there is a net southward volume transport through Fram Strait and, hence, no mass balance. Often the term temperature flux is used instead of heat flux in situations where a net volume transport occurs. Traditionally the heat transports into the Arctic Ocean have been computed relative to $-0.1^{\circ} \mathrm{C}$ and the freshwater fluxes relative to 34.8 , these values being taken as the mean temperature and mean salinity of the Arctic Ocean water column (Aagaard and Greisman, 1975; Aagaard and Carmack, 1989; Dickson et al., 2007). Whether or not it was possible to determine an adequate mean temperature and salinity of the Arctic Ocean at that time is questionable. It is also likely that the mean temperature and salinity would have changed in $40 \mathrm{yr}$ considering the reported variability of the inflow temperature and salinity and the increased temperature observed in the AW layer in the Arctic Ocean (Quadfasel et al, 1991; Carmack et al., 1995; Polyakov et al., 2005; Beszczynska-Möller, 2012).

Rudels et al. (2008) used, when working on single sections, variable reference temperatures and salinities. The mean temperature of the (southward) outflow and the mean salinity of the (northward) inflow, respectively, were computed for each section and used as reference values for that section. The choice made the outflow carry no heat and the inflow carry no freshwater and the fluxes were then closely connected to the actual situation in Fram Strait during the observation time. Here, with two sections, the heat and freshwater fluxes for each year are computed relative to the mean temperature and mean salinity of the total transports (into and out of the box in both cases). This choice again relates the heat (temperature) transport to the waters present at the actual time of the observation and also gives a possibility to relate the variations of the temperature and freshwater transports to the variations of the mean salinity and temperature of the waters present (Table 2). The choice diminishes the effect of the violated mass conservation by keeping the reference temperature (salinity) close to the mean temperature (salinity) of the exchanged waters. This minimises the effect of the mass (im)balance since the excess mass flux has temperature (salinity) close to the reference temperature (salinity). The heat loss and freshwater input in the strait however, are almost independent of the reference value.

\subsubsection{Results}

Heat and freshwater transports (Fig. 7) are computed for the east-west section pairs relative to the mean temperature and the mean salinity of the total volume transport (Table 2). The transports of heat and freshwater would be the same through both of the sections if there was no exchange with the atmosphere and with sea ice. For all four years there is net heat transport into the box and freshwater transport out of the box. The mass of ice equivalent to the net freshwater divergence from the area between the sections is

$\mathrm{m}_{\mathrm{fw}}=\rho_{\mathrm{w}} \times \mathrm{V}_{\mathrm{fw}}$

where $\rho_{\mathrm{w}}$ is the density of sea water and $\mathrm{V}_{\mathrm{fw}}$ is the volume of freshwater. The heat needed to melt this mass of ice is

$Q=\Delta H_{\text {fus }} \times \mathrm{m}_{\mathrm{fw}}$

where $\Delta H_{\text {fus }}=3.33 \times 10^{5} \mathrm{~J} \mathrm{~kg}^{-1}$ is the latent heat of fusion of water.

In 2004, the freshwater imbalance is $61 \mathrm{mSv}$, corresponding to a heat input of $21 \mathrm{TW}$ (Table 6a). In 2004, the lateral convergence of heat, i.e., the ocean heat loss in the area between the sections, is only 2 TW. Year 2004 is studied in more detail and the other years are presented in Table 6 a. It is first estimated whether the additional $19 \mathrm{TW}$ of the heat needed in 2004 to melt the ice corresponding to the net freshwater divergence could be added from the atmosphere and the radiation. From the ERA Interim data the atmospheric heat input averaged over two months (July, August) is $16 \mathrm{TW}$ for an area located between the sections, from a spatial resolution of $0.75^{\circ}$, (latitude 79.5 to $82.5^{\circ} \mathrm{N}$, and longitude $12^{\circ} \mathrm{W}$ to $9.75^{\circ} \mathrm{E}$ ). This could melt $47 \mathrm{mSv}$ of ice, which is in the same order of magnitude as the $61 \mathrm{mSv}$ of freshwater estimated to leave the area. With the additional ice melt of $7 \mathrm{mSv}$ from the heat lost by the ocean, the ice melt occurring in the strait based on geostrophic computations is nearly explained. In the other years the atmospheric heat input for the areas between the sections, combined with oceanic heat loss, is sufficient to melt the estimated amount of ice (Table 6).

The freshwater input from total precipitation is also estimated. Evaporation is small. The cumulative precipitation and evaporation from ERA Interim data are integrated over time (July-August) and amount to $0.062 \mathrm{~m}$ per unit area in 2004. The net precipitation minus evaporation for an area between the two sections is, thus, $1.0 \times 10^{10} \mathrm{~m}^{3}$. This amount equals to $1.9 \mathrm{mSv}$, about $3 \%$ of the estimated freshwater transport in 2004 (Table 6b). Adding this to the above computed values of atmospheric ice melt $(47 \mathrm{mSv})$ and oceanic ice melt $(7 \mathrm{mSv})$ gives $56 \mathrm{mSv}$ as compared to the $61 \mathrm{mSv}$ from geostrophy. The other years are presented in Table 6 .

There is no reason to expect a balance between oceanic heat loss and ice melt, and these estimates only show that the heat loss is compatible with the sea ice melt between the sections. Less than half of the study area was ice-covered at the end of the measurement period (NSIDC Sea Ice Index).

The heat and freshwater transports are computed with variable reference temperature and salinity values. The transports were also computed relative to temperature $-0.1^{\circ} \mathrm{C}$ and to salinity 34.8 , as well as relative to salinity 34.9 , which has been used by various authors, e.g., Holfort et al. (2008) and de Steur et al. (2009) for Fram Strait computations.

The heat loss averaged over $4 \mathrm{yr}$ from the ocean between the two zonal sections can be estimated as $11 \mathrm{TW}$. A little over $30 \%$ of the heat transported northward through the 
Table 6. Heat and freshwater (fw) convergence/divergence from hydrographic and ERA Interim data, with the varying averages as reference temperature and salinity. (a) Heat lost by the ocean (column 2) and heat input from the atmosphere between the two zonal sections (column 3 ) as compared with the heat required to balance the freshwater transport via ice melt (column 1). (b) Freshwater divergence from the hydrographic data (last column) as compared with the divergence of freshwater possible from the oceanic heat loss (column 1), sea ice melt possible from the ERA Interim atmospheric data (2) and precipitation and evaporation (downward fluxes positive) (column 5) from the ERA Interim data. Precipitation (P) and evaporation (E) from the ERA Interim data are computed for an area with ice concentration less than $90 \%$.

\begin{tabular}{|c|c|c|c|c|c|c|c|c|}
\hline & \multicolumn{7}{|l|}{ (a) } & \\
\hline & Year & $\begin{array}{l}\text { 1. Heat req. to } \\
\text { balance fw transport }\end{array}$ & \multicolumn{2}{|c|}{$\begin{array}{l}\text { 2. Oceanic } \\
\text { heat loss }\end{array}$} & \multicolumn{2}{|c|}{$\begin{array}{l}\text { 3. Heat input from } \\
\text { atm. (ECMWF data) }\end{array}$} & $2+3$ & \\
\hline & 1984 & $13 \mathrm{TW}$ & $25 \mathrm{TW}$ & & $12 \mathrm{~T}$ & & $37 \mathrm{TW}$ & \\
\hline & 1997 & $3 \mathrm{TW}$ & $5 \mathrm{TW}$ & & $11 \mathrm{~T}$ & & $16 \mathrm{TW}$ & \\
\hline & 2002 & $20 \mathrm{TW}$ & $14 \mathrm{TW}$ & & $16 \mathrm{~T}$ & & $30 \mathrm{TW}$ & \\
\hline & 2004 & $21 \mathrm{TW}$ & $2 \mathrm{TW}$ & & $16 \mathrm{~T}$ & & $18 \mathrm{TW}$ & \\
\hline \multicolumn{9}{|l|}{ (b) } \\
\hline Year & $\begin{array}{l}\text { 1. Divergence } \\
\text { of fw possible } \\
\text { from oceanic } \\
\text { heat loss }\end{array}$ & $\begin{array}{l}\text { 2. Sea ice melt } \\
\text { possible from } \\
\text { ECMWF atm. } \\
\text { fluxes }\end{array}$ & 3. $\mathrm{P}$ & 4. E & & $\begin{array}{l}\text { 5. } \mathrm{P}+\mathrm{E} \text { per } \\
\text { time } \times \text { area }\end{array}$ & $1+2+5$ & $\begin{array}{l}\text { fw } \\
\text { divergence }\end{array}$ \\
\hline 1984 & $72 \mathrm{mSv}$ & $35 \mathrm{mSv}$ & $0.053 \mathrm{~m}$ & -0.0 & $010 \mathrm{~m}$ & $0.6 \mathrm{mSv}$ & $108 \mathrm{mSv}$ & $37 \mathrm{mSv}$ \\
\hline 1997 & $13 \mathrm{mSv}$ & $32 \mathrm{mSv}$ & $0.058 \mathrm{~m}$ & -0.0 & $009 \mathrm{~m}$ & $1.2 \mathrm{mSv}$ & $46 \mathrm{mSv}$ & $8 \mathrm{mSv}$ \\
\hline 2002 & $42 \mathrm{mSv}$ & $47 \mathrm{mSv}$ & $0.053 \mathrm{~m}$ & +0.0 & $002 \mathrm{~m}$ & $1.6 \mathrm{mSv}$ & $90 \mathrm{mSv}$ & $58 \mathrm{mSv}$ \\
\hline 2004 & $7 \mathrm{mSv}$ & $47 \mathrm{mSv}$ & $0.062 \mathrm{~m}$ & +0.0 & $002 \mathrm{~m}$ & $1.9 \mathrm{mSv}$ & $56 \mathrm{mSv}$ & $61 \mathrm{mSv}$ \\
\hline
\end{tabular}

$79^{\circ} \mathrm{N}$ section is lost between the sections estimated from varying reference temperatures. Using the reference temperature $-0.1^{\circ} \mathrm{C}$ gives a $60 \%$ heat loss between the sections. The net freshwater transport southward averaged over $4 \mathrm{yr}$ through $79^{\circ} \mathrm{N}$ is from varying reference salinities $57 \mathrm{mSv}$ and $15 \mathrm{mSv}$ through the northern section. Using reference salinities of 34.8 and 34.9 , we get 66 and $75 \mathrm{mSv}$ across $79^{\circ} \mathrm{N}$ and 25 and $34 \mathrm{mSv}$ through the northern section. The freshwater addition from the area between the sections, thus, is $41 \mathrm{mSv}$.

\section{Critique}

\subsection{Comparison of transport estimates from different methods}

\subsubsection{Northward and southward transports from zonal sections}

We have estimated the transports and the recirculation in Fram Strait for 1984, 1997, 2002 and 2004 as well as the transports through $0^{\circ}$-meridian between $78.8^{\circ} \mathrm{N}$ and $80^{\circ} \mathrm{N}$ for 1997, 2001 and 2003 from closed boxes, and for 2003 also between $78^{\circ} \mathrm{N}$ and $78.8^{\circ} \mathrm{N}$. The transports through $0^{\circ}$ meridian were also computed for 1997, 2001 and 2003 between $78^{\circ} \mathrm{N}$ and $80^{\circ} \mathrm{N}$ with no constraints applied.

The mean net volume transport through Fram Strait based on the four zonal section pairs is estimated as $3.1 \mathrm{~Sv}$ south- ward. In order to compare the present results with the results of Rudels et al. (2008), who obtained a mean transport of $2.7 \mathrm{~Sv}$ before using budget considerations that brought the net transport down to $1.7 \mathrm{~Sv}$ (Table 7), the transports are computed for a smaller section from the Greenland shelf break to the Svalbard shelf break at $79^{\circ} \mathrm{N}$, i.e., from $6^{\circ} \mathrm{W}$ to $9^{\circ} \mathrm{E}$. This gives a somewhat smaller estimate of $2.7 \mathrm{~Sv}$ southward. About $0.5 \mathrm{~Sv}$ was expected to flow southward on the Greenland shelf by Rudels et al. (2008) and that seems to be reasonable also from the present estimates (Tables 2 and 7, Fig. 1). Recent modelling results by Fieg et al. (2010), give an 11yr mean net volume transport of $2.0 \mathrm{~Sv}$ southward through Fram Strait.

The 2002 results are also compared with Oden results obtained by Marnela et al. (2008) using the northern section. They obtained 3.6 Sv northward on their eastern section and $5.1 \mathrm{~Sv}$ southward on the western section and $0.5 \mathrm{~Sv}$ northward between sections. Adding these values up gives a southward transport of only $1 \mathrm{~Sv}$ through the northern section as compared with the $4.1 \mathrm{~Sv}$ obtained here. For the less wide section that Rudels et al. (2008) used for the section at $79^{\circ} \mathrm{N}$ $3.4 \mathrm{~Sv}$ is here found, which is slightly less than the $3.6 \mathrm{~Sv}$ presented by Rudels et al. (2008).

Using a similar method for 1984, Houssais et al. (1995) obtain a net southward transport of $1.6 \mathrm{~Sv}$ whereas here we find 2.2 Sv southward. The differences are larger in the transports of individual water masses. Both get the same amount of freshwater, $40 \mathrm{mSv}$, added between the sections. Houssais et al. (1995) also suggest that their $0.7 \mathrm{~Sv}$ of AW converging 
Table 7. Net volume transports at $79^{\circ} \mathrm{N}$ from zonal sections and from Rudels et al. (2008). Full section and from $6^{\circ} \mathrm{W}$ to $9^{\circ} \mathrm{E}$. Negative transports are southward

\begin{tabular}{lrrcc}
\hline & $\begin{array}{c}\text { Whole } \\
\text { section }\end{array}$ & $6^{\circ} \mathrm{W}-9^{\circ} \mathrm{E}$ & $\begin{array}{c}\text { Whole section } \\
\text { Rudels et al. (2008) }\end{array}$ & $\begin{array}{c}6^{\circ} \mathrm{W}-9^{\circ} \mathrm{E} \text { based on } \\
\text { Rudels et al. (2008) }\end{array}$ \\
\hline All years (av.) & -3.1 & -2.7 & $-2.7\left(-1.7^{*}\right)$ & -2.1 \\
1984 & -2.2 & -2.0 & -1.0 & -0.8 \\
1997 & -4.2 & -4.2 & -4.1 & -4.1 \\
2002 & -4.1 & -3.4 & -3.6 & - \\
2004 & -1.8 & -1.1 & -2.1 & -1.5 \\
\hline
\end{tabular}

* Computed as a mean of 16 summer sections taken between 1980 and 2005, and then modified with budget considerations.

in the area might be diluted by Polar surface water, but the results presented here suggest that the $0.7 \mathrm{~Sv}$ of $\mathrm{AW}$ converging in the area could be mixed with the intermediate waters below.

\subsubsection{Meridional Sections and recirculation}

The transports through $79^{\circ} \mathrm{N}$ can be computed for 2003 from the meridional section boxes. With constraints applied the net volume transport across $79^{\circ} \mathrm{N}$ is $3.1 \mathrm{~Sv}$ southward. This is close to the $3.3 \mathrm{~Sv}$ obtained by Rudels et al. (2008) from the same Lance data. The 2003 Polarstern section taken less than one month later than the Lance section gave a transport of 1.4 Sv southward (Rudels et al., 2008). Temporal variance this large is possible, as seen in the net volume flow from mooring data and also captured by the models (Fieg et al., 2010, Fig. 9).

For 1997 and 2001 only the fluxes through the part of the $79^{\circ} \mathrm{N}$ section east of $0^{\circ}$ longitude can be computed with constraints applied, the corresponding transports are $0.4 \mathrm{~Sv}$ and $0.7 \mathrm{~Sv}$ northward as compared with the 1.2 and $2.0 \mathrm{~Sv}$ northward from the method used by Rudels et al. (2008). From the zonal section pairs with constraints applied the transport for 1997 on the eastern side of the $79^{\circ} \mathrm{N}$ section is $0.7 \mathrm{~Sv}$ northward.

From the meridional section computations with and without constraints applied the results between $78.8^{\circ} \mathrm{N}$ and $80^{\circ} \mathrm{N}$ are of the same order and direction. The westward recirculation between $78.8^{\circ} \mathrm{N}$ and $80^{\circ} \mathrm{N}$ is largest in 2003 .

For 1997 no recirculation was found from the zonal section pair, but from the meridional section a recirculation of 1.3 Sv westward was obtained. The data in the 1997 northern section are sparse and aliasing is likely to occur.

\subsection{Sources of error}

\subsubsection{Data}

Most of the data have not been smoothed. However, since the geostrophic computations integrate the density field, smaller disturbances tend to cancel out. Some spikes have been removed by linear interpolation, but the datasets still contain small spikes, e.g., the 2003 Lance data for the northern box has a probable salinity spike of 0.004 present at a couple of stations. Such a spike perturbs the velocities by about $1 \times 10^{-5} \mathrm{~ms}^{-1}$, which then affects the water column above the spike since the velocities are first set to zero near the bottom. The transport estimate assuming the distance between stations to be $20 \mathrm{~km}$ and depth $1 \mathrm{~km}$ above the spike, amounts to a missed volume of $0.2 \mathrm{mSv}$. This difference is small enough to be ignored.

The data close to the surface often are of poor quality. The largest depths that have been extrapolated to the surface by using constant values are on a station in 2001 from about 70 dbar to the surface, and in 2003 on a station from $29 \mathrm{dbar}$ to the surface.

The data do not always reach close to the bottom of the ocean floor. Two of the 2002 and two of the 2003 station casts miss more than or about $1000 \mathrm{~m}$ of the water column above the bottom (Figs. 3 and 5). The transports for these missed areas are not compensated for in the transport estimates. The transports were computed for the 2003 meridional section (southern box) excluding these two shallow casts from the section. The westward and eastward transports through the meridional section were reduced by over $1 \mathrm{~Sv}$, but the recirculation of both the total water column and of AW were reduced by less than $0.1 \mathrm{~Sv}$.

The location and length of the northern section vary from year to year, sometimes crossing the Yermak Plateau and sometimes not. The $79^{\circ} \mathrm{N}$ sections also are of different lengths. The 1997 and 2002 sections are taken over 2 months apart and, hence, not synoptic considering the variation in the strait. Aliasing due to too few stations may also occur.

\subsubsection{Method}

We have assumed that the transports not observed in the strait, because of the sections not reaching the coasts, are about equal on both sections and cancel out, and that the net flow passing one section also has to cross the other section, apart from the added ice melt. No heat or salt is allowed to accumulate in the deep part of the box during that time. These are assumptions. The part of the Greenland shelf missed by 
the sections is up to almost $200 \mathrm{~km}$ wide and on the Svalbard shelf about $50 \mathrm{~km}$ is missed (Fig. 2). Rudels et al. (2008) estimated up to $1 \mathrm{~Sv}$ of water on the Greenland shelf passing southward beyond the standard $79^{\circ} \mathrm{N}$ section. The transport on the Svalbard shelf east of the standard $79^{\circ} \mathrm{N}$ section can be estimated from the 2003 data (from $9^{\circ} \mathrm{E}$ to $11^{\circ} \mathrm{E}$ ) as $0.1 \mathrm{~Sv}$ northward and has been estimated by Walczowski et al. (2005) as about $0.1 \mathrm{~Sv}$ northward at their section $\mathrm{S}$ (at about $78^{\circ} \mathrm{N}$ ) and about $0.1 \mathrm{~Sv}$ southward at their section $\mathrm{Z}$ (about $78^{\circ} 15^{\prime} \mathrm{N}$ ) from baroclinic computations. The deformation radius on the Svalbard shelf is estimated as about $10 \mathrm{~km}$ from the 2003 data.

The velocities between stations cannot be readily deduced from the density field close to the bottom due to the nonuniform topography. The method of Jacobsen and Jensen used to estimate the velocities at the bottom of the deeper station in a station pair only takes into account the difference between the station properties at the bottom depth of the shallower station and the velocity for the deep station close to bottom is extrapolated from that single difference (Fig. 6).

Having the geostrophic velocity set to zero near the bottom without applying constraints leads to convergences between the zonal sections and imbalances with net inflows into the box ranging from $0.5 \mathrm{~Sv}$ in 1997 to $3.5 \mathrm{~Sv}$ in 1984 and a net outflow (divergence) of $0.7 \mathrm{~Sv}$ in 2002 (Table 1).

It is clear that the transports are highly dependent on the constraints (Table A1) used as well as on the available stations that form the section. The 1984 result is tested for aliasing by removing one station from the data. The net transport changes very little if the station is removed from the deep part of the strait, up to about $0.1 \mathrm{~Sv}$, but the northward and southward transports can both differ by $2 \mathrm{~Sv}$. Although the removal of a station from the section does not affect the net transports much, it can have large impacts on the individual northward and southward transports. However, if the station is removed from the West Spitsbergen Current or the East Greenland Current on the slopes, even the net transport can change by more than $1 \mathrm{~Sv}$.

The depth of about $2700 \mathrm{~m}$ ( $2744 \mathrm{dbar}$ ) is used to block the deeper waters in the northern section from crossing the strait. However, the sill depth is cited as $2600 \mathrm{~m}$ in literature and studies of the bottom bathymetry in the Fram Strait show a very complex structure (e.g., Klenke and Schenke, 2002). We have on the $79^{\circ} \mathrm{N}$ sections 1-7 stations that reach deeper than $2600 \mathrm{~m}$. Should we use that as a limiting depth, we would need an extra constraint for the deep part of the $79^{\circ} \mathrm{N} \mathrm{sec-}$ tion assuming that the sill is at its shallowest between the sections. This is tested with the 2004 data and results give nearly the same volume transport as already presented, the difference between the results being less than about $2 \%$, except for the deep waters and AW. The largest differences are in the order of $0.1 \mathrm{~Sv}$. The freshwater produced between the sections increases by $0.5 \mathrm{mSv}$. Heat/temperature seems to be the most sensitive of the three variables showing an increase of $23 \%(0.5 \mathrm{TW})$ of heat lost between the sections. Mainly the difference is due to the more positive fluxes (warm Atlantic waters northward and cold deep water southward) at $79^{\circ} \mathrm{N}$ section.

\subsubsection{Strait dynamics}

There are eddies in Fram Strait and its vicinity, typically of diameter of 20-40 km with persistence time of 20-30 days (Johannessen et al., 1987; Quadfasel et al., 1987). Mesoscale eddies are an important mechanism by which AW may be recirculated from the WSC (Gascard et al., 1988; Schlichtholz and Houssais, 2002). These eddies may be missed by the hydrographic sections or misinterpreted due to aliasing, e.g., if only one side of eddy is measured.

Fahrbach et al. (2001) report a recirculation of $2.6 \pm 0.1 \mathrm{~Sv}$ just east of $0^{\circ} \mathrm{E}$ between $78^{\circ} 50^{\prime} \mathrm{N}$ and $79^{\circ} \mathrm{N}$, and some of the recirculation through the meridional section may be missed having it located at $0^{\circ}$-meridian.

With the constraints applied the convergence or divergence of a specific water mass in the box can be up to $0.5 \mathrm{~Sv}$ or more. The maximum convergence, $0.7 \mathrm{~Sv}$, occurs in the AW in 1984 and the maximum divergence, $0.9 \mathrm{~Sv}$, in the surface water in 2004 (Fig. 8). This indicates that diapycnal mixing occurs between the sections and affects a substantial fraction of the water masses. The main mixing is isopycnal as can be seen from the transformations of the water masses between the waters entering and leaving the boxes. The temperaturesalinity shifts are mainly isopycnal (Fig. 8).

The salinity of multi-year ice is about $2-3$ psu and a little bit more in the first year ice at the end of summer and again slightly more at the beginning of the summer (Untersteiner, 1961). The salt contained in the sea ice crossing the box borders is not considered in the computations, but the salt released to the area between the zonal sections by melting is present in the data causing a small error less than $0.01 \mathrm{~Sv}$ in volume transports and about $0.01-0.03 \mathrm{mSv}$ in freshwater transports (estimated assuming 4 psu sea ice).

The daily mean winds at $10 \mathrm{~m}$ height are obtained from the Era Interim Reanalyses of ECMWF. The Ekman transport of water near the surface can be estimated from the data. Using the daily mean winds gives Ekman transports up to $0.5 \mathrm{~Sv}$ during the measurement periods, however, these transports nearly cancel out during the whole length of the period being $\pm 0.005 \mathrm{~Sv}$. The Ekman transports are considered small and not included in the computations.

\section{Discussion and conclusions}

The mean net volume transport for the observed four years having velocity set to zero near the bottom and with no constraints applied is $2.9 \mathrm{~Sv}$ southward through the $79^{\circ} \mathrm{N} \mathrm{sec-}$ tion and $4.5 \mathrm{~Sv}$ southward through the northern section, with an imbalance of $1.6 \mathrm{~Sv}$ between the sections. Applying the constraints changes the transport to $3.1 \mathrm{~Sv}$ and reduces the 
imbalance between the sections to less than $0.1 \mathrm{~Sv}$. The net volume transports obtained from applying the constraints fall between the volume transports at the two sections with no constraints applied, i.e., the net volume transports increase at the $79^{\circ} \mathrm{N}$ section and decrease at the northern section except in 2002 the opposite. The sections in 2002 are exceptional in that the southward net transport without constraints is larger at the $79^{\circ} \mathrm{N}$ section than at the northern section. This is only partly explained by the extending of the section at $79^{\circ} \mathrm{N}$ furthest to the west in 2002, the flow estimated for the shelf part being $0.7 \mathrm{~Sv}$ (Fig. 2, Tables 1, 2 and 7). The transport southward through the northern section is smallest in 2002. However, a gap with no observations between $1200 \mathrm{~m}$ and the bottom exists on the northern section (see Fig. 3).

The individual northward and southward volume fluxes are smaller than those obtained by direct current measurements (e.g., Schauer et al., 2008), but the net transports are of the same order, perhaps larger. If correct, this would require a larger inflow over the Barents Sea than the slightly above $2 \mathrm{~Sv}$ that has previously been estimated (e.g., Smedsrud et al., 2010) or a smaller outflow through the Canadian Arctic Archipelago than the $2 \mathrm{~Sv}$ given in most references (e.g., Melling et al., 2008). Recent results (e.g., Skagseth et al., 2011) find $3 \mathrm{~Sv}$ inflow to the Barents Sea.

The recirculation of AW in Fram Strait is estimated as about $2 \mathrm{~Sv}$ from both the zonal and meridional sections. The recirculation of intermediate waters is smaller and that of surface waters only noticeable in 2002 . The recirculation seems to be largest at and south of $79^{\circ} \mathrm{N}$ and clearly weakens northwards, as is seen from the meridional sections. This supports the assumption that the strong recirculation area is located south of $81-82^{\circ} \mathrm{N}$ as already suggested by Rudels (1987). Part of the recirculation may be located east of the $0^{\circ}$ meridian and would then be missed in the meridional sections. Almost $50 \%$ of the AW entering the strait from the south recirculates as has previously been estimated by, e.g., Rudels (1987), Bourke et al. (1987) and Manley (1995).

The north-south section is also located in the vicinity of a semi-permanent topographically trapped eddy of $60 \mathrm{~km}$ in diameter near the Molloy Deep (Wadhams and Squire,1983; Bourke et al., 1987; Johannessen et al., 1987), which causes the flow near $79^{\circ} 30^{\prime} \mathrm{N}$ and $3^{\circ} \mathrm{E}$ to be westward north of the eddy and eastward south of it. In 1997 and 2003, the westward transports between $79^{\circ} 30^{\prime} \mathrm{N}$ and $80^{\circ} \mathrm{N}$, are smaller than elsewhere and in 2001 eastward.

The circulation around Yermak Plateau is similar to that obtained by Marnela et al. (2008) for the 2002 data. There is northward flow of AW in the east. The results also support the southward flow along Yermak Plateau's eastern flank (Fig. 3).

There are large differences in the heat/temperature and freshwater transports during the different years. The results are nevertheless reasonable. The net heat/temperature transport across the southern sections is, except in 1997, in the range of the transports found from direct current measurements (Schauer et al., 2004, 2008). The smaller transports through the northern sections indicate that a substantial heat loss occurs just north of $79^{\circ} \mathrm{N}$.

The transport of liquid freshwater, $60 \mathrm{mSv}$ in 2004 and $50 \mathrm{mSv}$ in 2002 and less in the earlier years, is almost as large as the ice export (Dickson et al., 2007) and somewhat smaller than estimated by Rabe et al. (2009). The difference between the northern and southern sections shows that a large part of the freshwater is added to the water column just north of Fram Strait, largely in the area between the sections, mainly through ice melt.

The results presented in Table 2 imply that when the waters inside the box are warm more heat is carried northward and more heat is being used to melt sea ice inside the box. Across $79^{\circ} \mathrm{N}$ the freshwater transport is largest (smallest) when the volume transport is largest (smallest). This might be interpreted as the salinity of low-salinity surface water having low year to year (summer) variance.

In the deep and in the intermediate waters below the density surface 28.06 there is a net southward transport at $79^{\circ} \mathrm{N}$ of $0.6 \mathrm{~Sv}$ in $1984,0.5 \mathrm{~Sv}$ in $1997,0.7 \mathrm{~Sv}$ in 2002 and $0.1 \mathrm{~Sv}$ northward in 2004. The mean of the four years equals $0.4 \mathrm{~Sv}$ net southward transport, a single value that was used as one constraint on the deep exchanges in the earlier work on the transports through single sections at $79^{\circ} \mathrm{N}$ (Rudels et al., 2008), and suggests that such constraint on single sections might be realistic.

The method used here is rather simple. It requires only the use of hydrographic data with constraints. The individual northward and southward transports obtained for heat (temperature) and freshwater are somewhat arbitrary, due to the choice of reference temperature and salinity, but also due to the limited number of stations available which allows for some smaller scale features to pass unnoticed. The results for the net transports through Fram Strait as well as for the heat lost and freshwater formed between the sections, however, are comparable to those from more sophisticated methods.

\section{Appendix A}

\section{Geostrophic method and the method of Jacobsen and Jensen}

Geostrophic balance for the velocity component normal to the line connecting the CTD stations, or $\mathrm{x}$-axis, can be written as follows:

$v \cdot 2 \Omega \sin \phi=-\frac{1}{\rho} \frac{\partial p}{\partial x}$

where $v$ is the velocity, $\Omega$ is the angular velocity of Earth $\left(7.292 \times 10^{-5} \mathrm{rad} \mathrm{s}^{-1}\right), \varphi$ is latitude, $\rho$ is density and $p$ is pressure.

After having set velocity to zero at the bottom of the shallower station of a pair, the method of Jacobsen and 
Table A1. Volume transports (Sv) as obtained from combinations of constraints. (a) constraints 1, 2, 5 and where applicable 6 are applied. (b) constraints 1, 5 and where applicable 6 are applied. (c) constraint 5 and where applicable 6 is applied. (d) constraint 1 is applied. (e) constraints 2 and 3 are applied.

\begin{tabular}{|c|c|c|c|c|c|c|}
\hline & \multicolumn{3}{|c|}{$79^{\circ} \mathrm{N}$} & \multicolumn{3}{|c|}{ North } \\
\hline Year & Northward & Southward & Net & Northward & Southward & Net \\
\hline \multicolumn{7}{|l|}{ (a) } \\
\hline 1984 & 7.60 & -9.90 & -2.30 & 5.12 & -7.38 & -2.26 \\
\hline 1997 & 3.59 & -8.26 & -4.67 & 3.99 & -8.65 & -4.66 \\
\hline 2002 & 9.73 & -13.68 & -3.95 & 2.98 & -6.86 & -3.88 \\
\hline 2004 & 7.65 & -10.75 & -3.10 & 5.25 & -8.30 & -3.04 \\
\hline mean & 7.14 & -10.65 & -3.50 & 4.33 & -7.80 & -3.46 \\
\hline std & 2.22 & 1.97 & 0.89 & 0.92 & 0.71 & 0.90 \\
\hline \multicolumn{7}{|l|}{ (b) } \\
\hline 1984 & 7.30 & -10.45 & -3.14 & 4.54 & -7.66 & -3.12 \\
\hline 1997 & 3.54 & -8.32 & -4.79 & 3.95 & -8.73 & -4.78 \\
\hline 2002 & 9.66 & -13.78 & -4.12 & 2.90 & -6.95 & -4.05 \\
\hline 2004 & 7.49 & -10.94 & -3.45 & 5.06 & -8.46 & -3.40 \\
\hline mean & 7.00 & -10.87 & -3.87 & 4.11 & -7.95 & -3.84 \\
\hline std & 2.20 & 1.95 & 0.64 & 0.80 & 0.70 & 0.64 \\
\hline \multicolumn{7}{|l|}{ (c) } \\
\hline 1984 & 7.77 & -9.20 & -1.43 & 3.97 & -8.26 & -4.28 \\
\hline 1997 & 3.85 & -7.94 & -4.09 & 3.74 & -9.04 & -5.30 \\
\hline 2002 & 9.54 & -13.97 & -4.44 & 2.99 & -6.82 & -3.82 \\
\hline 2004 & 8.31 & -9.82 & -1.51 & 4.19 & -9.10 & -4.91 \\
\hline mean & 7.37 & -10.23 & -2.87 & 3.72 & -8.31 & -4.58 \\
\hline std & 2.13 & 2.26 & 1.40 & 0.45 & 0.92 & 0.57 \\
\hline \multicolumn{7}{|l|}{ (d) } \\
\hline 1984 & 7.35 & -10.31 & -2.96 & 4.43 & -7.37 & -2.94 \\
\hline 1997 & 3.76 & -8.05 & -4.29 & 4.20 & -8.49 & -4.29 \\
\hline 2002 & 9.66 & -13.79 & -4.13 & 2.95 & -7.01 & -4.06 \\
\hline 2004 & 7.84 & -10.41 & -2.57 & 5.44 & -7.97 & -2.53 \\
\hline mean & 7.15 & -10.64 & -3.49 & 4.25 & -7.71 & -3.45 \\
\hline std & 2.14 & 2.05 & 0.74 & 0.89 & 0.57 & 0.74 \\
\hline \multicolumn{7}{|l|}{ (e) } \\
\hline 1984 & 7.92 & -9.15 & -1.23 & 3.84 & -7.75 & -3.92 \\
\hline 1997 & 4.22 & -7.70 & -3.48 & 4.81 & -8.17 & -3.37 \\
\hline 2002 & 9.93 & -13.64 & -3.71 & 3.11 & -6.46 & -3.35 \\
\hline 2004 & 8.87 & -9.57 & -0.71 & 5.74 & -7.79 & -2.05 \\
\hline mean & 7.74 & -10.01 & -2.28 & 4.37 & -7.54 & -3.17 \\
\hline std & 2.15 & 2.20 & 1.33 & 0.99 & 0.65 & 0.69 \\
\hline
\end{tabular}

Jensen (1926) is used for determining the velocities at the deeper station at all levels $j$ located below the deepest common level of the station pair. This involves computing the difference between the specific volume anomaly of the bottommost measurement of the shallow station $i$ and the specific volume anomaly at the corresponding pressure of the deep station $i+1$. The velocity is then obtained by dividing the anomaly difference $\Delta \delta_{i}$ by the distance $L_{i}$ between the stations and by Coriolis term $f(f=2 \Omega \sin \varphi)$, and multiplying by a depth dependent sum. For layers $j$ of thickness dh below the shallow station, we get:

$v_{i+1, j}=\frac{\Delta \delta_{i}}{L_{i} f} \sum_{k=1}^{j}\left(\Delta H_{i}-k \times \mathrm{d} h\right) / \Delta H_{i}$

where $j=1, \ldots, \Delta H_{i} / \mathrm{d} h$ and $\Delta H_{i}$ is the difference between the bottom depth of the deep station and the bottom depth of the shallow station. 


\section{Appendix B}

\section{Conservation constraints and the variational method}

The conservation constraints are: (1) salt is conserved between the sections, (2) volume, (3) salt, and (4) heat are conserved between the sections below the density surface 28.06 and above $2744 \mathrm{dbar}(5)$ volume is conserved on the northern section below $2744 \mathrm{dbar}$, and (6) volume is conserved below 750 dbar in the Sofia Deep.

The net transports of the baroclinic transports are balanced with barotropic velocities and the constraints become:

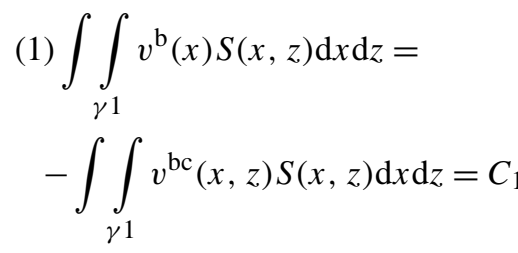

(2) $\iint_{\gamma 2} v^{\mathrm{b}}(x) d x d z=-\iint_{\gamma 2} v^{\mathrm{bc}}(x, z) \mathrm{d} x \mathrm{~d} z=C_{2}$

(3) $\iint_{\gamma 3} v^{\mathrm{b}}(x) S(x, z) \mathrm{d} x \mathrm{~d} z=$

$-\iint_{\gamma 3} v^{\mathrm{bc}}(x, z) S(x, z) \mathrm{d} x \mathrm{~d} z=C_{3}$

(4) $\iint_{\gamma 4} v^{\mathrm{b}}(x) \theta(x, z) \mathrm{d} x \mathrm{~d} z=$

$-\iint_{\gamma 4} v^{\mathrm{bc}}(x, z) \theta(x, z) \mathrm{d} x \mathrm{~d} z=C_{4}$

(5) $\iint_{\gamma 5} v^{\mathrm{b}}(x) \mathrm{d} x \mathrm{~d} z=-\iint_{\gamma 5} v^{\mathrm{bc}}(x, z) \mathrm{d} x \mathrm{~d} z=C_{5}$

(6) $\iint_{\gamma 6} v^{\mathrm{b}}(x) \mathrm{d} x \mathrm{~d} z=-\iint_{\gamma 6} v^{\mathrm{bc}}(x, z) \mathrm{d} x \mathrm{~d} z=C_{6}$

where $v^{\mathrm{b}}(\mathrm{x})$ is the depth-independent barotropic velocity, $v^{\mathrm{bc}}(\mathrm{x}, \mathrm{z})$ is the baroclinic velocity from the geostrophic computations. $S$ is salt, $\theta$ heat and $C_{k}$ constraint, $k=1, \ldots, 6$.

A variational approach is used to find the least energetic barotropic corrections needed to fulfil the constraints in a way similar to the method in Rudels et al. (2008). The barotropic velocity component $v^{\mathrm{b}}$ is computed by minimising the kinetic energy of the barotropic part using the method of Lagrangian multipliers (Lanczos, 1970; Wunsch, 1978;
Stommel and Veronis, 1981), where Lambda, $\lambda_{k}$, are the Lagrangian multipliers. Introducing $R_{k}$ for salt, heat and volume in Eq. (B1) we get:

$$
\begin{gathered}
\frac{\partial}{\partial v^{\mathrm{b}}}\left\{\iint_{\gamma 1} \frac{1}{2}\left(v^{\mathrm{b}}(x)\right)^{2} \mathrm{~d} x \mathrm{~d} z+\sum_{k=1}^{6} \lambda_{k}\right. \\
\left.\left(\iint_{\gamma k} v^{\mathrm{b}}(x) R_{k}(x, z) \mathrm{d} x \mathrm{~d} z-C_{k}\right)\right\}=0
\end{gathered}
$$

which in discrete form can be written as:

$$
\begin{aligned}
\frac{\partial}{\partial v^{\mathrm{b}}}\left\{\frac{1}{2} \sum_{i \in \gamma 1}\left(v_{i}^{\mathrm{b}}\right)^{2} \sum_{j \in \gamma 1} a_{i j}+\sum_{k=1}^{6} \lambda_{k}\right. \\
\left.\left(\sum_{i \in \gamma k}\left(v_{i}^{\mathrm{b}}\right) \sum_{j \in \gamma k} a_{i j} R_{i j}^{k}-C_{k}\right)\right\}=0
\end{aligned}
$$

where the sums are taken over the station halves $i$ and depths $z(i, j)$ corresponding to the intervals from $\gamma_{1}$ to $\gamma_{6}$. The temperature $\theta_{i j}$ and salinity $s_{i j}$ properties of each station are assumed to extend halfway to the neighbouring stations and $a_{i j}$ is the area where the property is considered valid: half of the distance to the neighbouring CTD station multiplied by the layer thickness dh. The two halves of the same station are treated separately and different reference velocities can be added to them (Rudels, 1987). After derivation this results to:

$a_{i}^{1} v_{i}^{\mathrm{b}}+\sum_{k=1}^{6} \lambda_{k} r_{i}^{k}=0$

where

$$
\begin{aligned}
& a_{i}^{k}=\sum_{j \in \gamma k} a_{i j} \\
& r_{i}^{k}=\sum_{j \in \gamma k} a_{i j} R_{i j}^{k} \\
& \text { i.e. } v_{i}^{\text {b }}+\sum_{k=1}^{6} \lambda_{k} \frac{r_{i}^{k}}{a_{i}^{1}}=0
\end{aligned}
$$

i.e. $\boldsymbol{v}^{\mathrm{b}}+\mathbf{B} \Lambda=0, \quad$ where

$\mathbf{B}=\left\{\frac{r_{i}^{k}}{a_{i}^{k}}\right\} \quad$ and $\quad \Lambda=\left\{\lambda_{k}\right\}$.

Writing Eq. (B1) as $\mathbf{A}^{T} \boldsymbol{v}^{\mathrm{b}}=\mathbf{C}, \quad$ where

$$
\mathbf{A}=\left\{r_{i}^{k}\right\} \quad \text { and } \quad \mathbf{C}=\left\{C_{k}\right\}
$$


and solving Eqs. (B6) and (B7) gives the barotropic velocity

$\boldsymbol{v}^{\mathrm{b}}=\mathbf{B}\left(\mathbf{A}^{T} \mathbf{B}\right)^{-1} \mathbf{C}$

and the new velocity becomes

$v_{i j}=v_{i j}^{\mathrm{bc}}+v_{i}^{\mathrm{b}}$.

Acknowledgements. This work has received support from the European Union 6th Framework Programme under grant agreement no. 018509, DAMOCLES and from 7th Framework Programme FP7 2007-2013 under the grant agreements no. 212643, THOR and no. 308290, NACLIM, and from the Academy of Finland (no. 210551). Roberta Pirazzini and Timo Vihma are warmly thanked for the help with the ECMWF ERA Interim data and the related computations. The editor and anonymous reviewers are thanked for their valuable comments that helped to improve the paper.

Edited by: J. M. Huthnance

\section{References}

Aagaard, K. and Carmack, E. C.: The role of sea ice and other fresh water in the Arctic circulation, J. Geophys. Res., 94, 1448514498, 1989.

Aagaard, K. and Greisman, P.: Toward new mass and heat budgets for the Arctic Ocean, J. Geophys. Res., 80, 3821-3827, 1975.

Aagaard, K., Darnall, C. and Greisman, P.: Year-long current measurements in the Greenland-Spitsbergen Passage, Deep Sea Res., 20, 743-746, 1973.

Beszczynska-Möller, A., Fahrbach, E., Schauer, U., and Hansen, E.: Variability in Atlantic water temperature and transport at the entrance to the Arctic Ocean, 1997-2010, ICES J. Mar. Sci., 69, 852-863, doi:10.1093/icesjms/fss056, 2012.

Bourke, R. H., Tunnicliffe, M. D., Newton, J. L., Paquette, R. G. and Manley, T. O.: Eddy near the Molloy Deep revisited, J. Geophys. Res., 92, C7, 6773-6776, 1987.

Bourke, R. H., Weigel, A. M., and Paquette, R. G.: The westward turning branch of the West Spitsbergen Current, J. Geophys. Res., 93, 14065-14077, 1988.

Carmack, E. C., Macdonald, R. W., Perkin, R. G., McLaughlin, F. A., and Pearson, R. J.: Evidence for warming of Atlantic water in the Southern Canadian Basin of the Arctic Ocean: Results from the Larsen-93 expedition, Geophys. Res. Lett., 22, 1061-1064, doi:10.1029/95GL00808, 1995.

de Steur, L., Hansen, E., Gerdes, R., Karcher, M., Fahrbach, E., and Holfort, J.: Freshwater fluxes in the East Greenland Current: A decade of observations. Geophys. Res. Lett., 36, L23611, doi:10.1029/2009GL041278, 2009.

Dickson R., Rudels, B., Dye, S., Karcher, M., Meincke, J., and Yashayaev, I.: Current estimates of freshwater flux through Arctic and subarctic seas. Prog. Oceanogr., 73, 210-230, doi:10.1016/j.pocean.2006.12.003, 2007.

Fahrbach, E., Meincke, J., Østerhus, S., Rohardt, G., Schauer, U., Tverberg, V., and Verduin, J.: Direct measurements of volume transports through Fram Strait. Polar Res., 20, 217-224, 2001.
Fieg, K., Gerdes, R., Fahrbach, E., Beszczynska-Möller, A., and Schauer, U.: Simulation of oceanic volume transports through Fram Strait 1995-2005. Ocean Dynam., 60, 491-502, doi:10.1007/s10236-010-0263-9, 2010.

Foldvik, A., Aagaard, K., and Tørresen, T.: On the velocity field of the East Greenland Current, Deep-Sea Res., 35, 1335-1354, 1988.

Gascard, J.-C., Kergomard, C., Jeannin, P.-F., and Fily, M.: Diagnostic study of the Fram Strait marginal ice zone during summer from 1983 and 1984 Marginal Ice Zone Experiment Lagrangian observations, J. Geophys. Res., 93, 3613-3641, 1988.

Holfort, J., Hansen, E., Østerhus, S., Dye, S., Jónsson, S., Meincke, J., Mortensen, J., and Meredith, M.: Freshwater fluxes east of Greenland, in: Arctic-Subarctic Ocean Fluxes, edited by: Dickson, R. R., Meincke, J., and Rhines, P., Springer, Dordrecht, 263287, 2008

Houssais, M.-N., Rudels, B., Friedrich, H., and Quadfasel, D.: Exchanges through Fram Strait, in: Nordic Seas Symposium on the Results of the Greenland Sea Project (GSP) 1987-1993, Extended Abstracts, edited by: Meincke, J., US National Science Foundation, Hamburg, 87-91, 1995.

Jacobsen, J. P. and Jensen, A. J. C.: Examination of hydrographical measurements from the research vessels Explorer and Dana during the summer of 1924, Conseil Permanent International pour l'Exploration de la Mer, Rap. Proces., 39, 31-84, 1926.

Johannessen, J. A., Johannessen, O. M., Svendsen, E., Shuchman, R. Manley, T., Campbell, W. J., Josberger, E. G., Sandven, S., Gascard, J. C., Olaussen, T., Davidson, K., and Van Leer, J.: Mesoscale eddies in the Fram Strait marginal ice zone during the 1983 and 1984 Marginal Ice Zone Experiments, J. Geophys. Res., 92, 6754-6772, 1987.

Karcher, M. J., Gerdes, R., Kauker, F., and Köberle, C.: Arctic warming: Evolution and spreading of the 1990s warm event in the Nordic seas and the Arctic Ocean, J. Geophys. Res., 108, 3034, doi:10.1029/2001JC001265, 2003.

Karcher, M., Gerdes, R., and Kauker, F.: Long-term variability of Atlantic water inflow to the Northern Seas: Insights from model experiments, in: Arctic-Subarctic Ocean Fluxes, edited by: Dickson, R. R., Meincke, J., and Rhines, P., Springer, Dordrecht, 111130, 2008.

Klenke, M. and Schenke, H. W.: A new bathymetric model for the central Fram Strait, Mar. Geophys. Res., 23, 367- 378, doi:10.1023/A:1025764206736, 2002.

Lanczos, C.: The variational principles of mechanics, 4th Edn., University of Toronto Press, Toronto, 418 pp., 1970.

Manley, T. O.: Branching of Atlantic water within the GreenlandSpitsbergen Passage: An estimate of recirculation, J. Geophys. Res., 100, 20627-20634, 1995.

Marnela, M., Rudels, B., Olsson, K. A., Anderson, L. G., Jeansson, E., Torres, D. J., Messias, M. J., Swift, J. H., and Watson, A. J.: Transports of Nordic Seas water masses and excess $\mathrm{SF}_{6}$ through Fram Strait to the Arctic Ocean. Prog. in Oceanogr., 78, 1-11, 2008.

Maslowski, W., Marble, D., Walczowski, W., Schauer, U., Clement, J. L., and Semtner, A. J.: On climatological mass, heat, and salt transports through the Barents Sea and Fram Strait from a panArctic coupled ice-ocean model simulation, J. Geophys. Res., 109, C03032, doi:10.1029/2001JC001039, 2004. 
Melling, H., Agnew, T. A., Falkner, K. K., Greenberg, D. A., Lee, C. M., Münchow, A., Petrie, B., Prinsenberg, S. J., Samuelson, R. M., and Woodgate, R. A.: Fresh-water Fluxes via Pacific and Arctic outflows across the Canadian Polar Shelf, in: ArcticSubarctic Ocean Fluxes, edited by: Dickson, R. R., Meincke, J., and Rhines, P., Springer, Dordrecht, 193-247, 2008.

Padman, L. and Erofeeva, S.: A barotropic inverse tidal model for the Arctic Ocean, Geophys. Res. Lett., 31, L02303, doi:10.1029/2003GL019003, 2004.

Palfrey Jr., K. M.: Physical oceanography of the northern part of the Greenland Sea in the summer of 1964, MS thesis, University of Washington, Seattle, 63 pp., 1967.

Polyakov, I. V., Beszczynska, A., Carmack, E., Dmitrenko, I., Fahrbach, E., Frolov, I. E., Gerdes, R., Hansen, E., Holfort, J., Ivanov, V. V., Johnson, M. A., Karcher, M., Kauker, F., Morison, J., Orvik, K. A., Schauer, U., Simmons, H. L., Skagseth, Ø., Sokolov, V. T., Steele, M., Timokhov, L. A., Walsh, D., and Walsh, J. E.: One more step toward a warmer Arctic, Geophys. Res. Lett., 32, L17605, doi:10.1029/2005GL023740, 2005.

Quadfasel, D., Gascard, J.-C., and Koltermann, K.-P.: Large-scale oceanography in Fram Strait during the 1984 Marginal Ice Zone Experiment, J. Geophys. Res., 92, 6719-6728, 1987.

Quadfasel, D., Sy, A., Wells, D., and Tunik, A.: Warming in the Arctic, Nature, 350, p. 385, doi:10.1038/350385a0, 1991.

Rabe, B., Schauer, U., Mackensen, A., Karcher, M., Hansen, E., and Beszczynska-Möller, A.: Freshwater components and transports in the Fram Strait - recent observations and changes since the late 1990s, Ocean Sci., 5, 219-233, doi:10.5194/os-5-219-2009, 2009.

Rudels, B.: On the mass balance of the Polar Ocean, with special emphasis on the Fram Strait, Norsk Polarinst. Skri., 188, 53 pp., 1987.

Rudels, B., Marnela, M., and Eriksson, P.: Constraints on estimating mass, heat and freshwater transports in the Arctic Ocean: An Exercise, in: Arctic-Subarctic Ocean Fluxes, edited by: Dickson, R. R., Meincke, J., and Rhines, P., Springer, Dordrecht, 315-341, 2008.

Schauer U., Fahrbach E., Østerhus S., and Rohardt G.: Arctic warming through the Fram Strait: Oceanic heat transports from 3 years of measurements, J. Geophys. Res., 109, C06026, doi:10.1029/2003JC001823, 2004.
Schauer, U., Beszczynska-Möller, A., Walczowski, W., Fahrbach, E., Piechura, J., and Hansen, E.: Variation of measured heat flow through the Fram Strait between 1997 and 2006, in: ArcticSubarctic Ocean Fluxes, edited by: Dickson, R. R., Meincke, J., and Rhines, P., Springer, Dordrecht, 65-85, 2008.

Schlichtholz, P. and Houssais, M. N.: An inverse modeling study in Fram Strait. Part I: dynamics and circulation, Deep-Sea Res., 46, 1083-1135, 1999.

Schlichtholz, P. and Houssais, M.-N.: An overview of the $\theta$-S correlations in Fram Strait based on the MIZEX 84 data, Oceanologia, 44, 243-272, 2002.

Skagseth, Ø., Drinkwater, K. F., and Terrile, E.: Wind- and buoyancy-induced transport of the Norwegian Coastal Current in the Barents Sea, J. Geophys. Res., 116, C08007, doi:10.1029/2011JC006996, 2011.

Smedsrud, L. H., Ingvaldsen, R., Nilsen, J. E. Ø., and Skagseth, Ø.: Heat in the Barents Sea: transport, storage, and surface fluxes, Ocean Sci., 6, 219-234, doi:10.5194/os-6-219-2010, 2010.

Stommel, H. and Veronis, G.: Variational inverse method for study of ocean circulation, Deep-Sea Res., 28, 1147-1160, 1981.

Teigen, S. H., Nilsen, F., Skogseth, R., Gjevik, B., and Beszczynska-Möller, A.: Baroclinic instability in the West Spitsbergen Current. J. Geophys. Res., 116, C07012, doi:10.1029/2011JC006974, 2011.

Untersteiner, N.: On the mass and heat budget of Arctic sea ice, Arch. Meteorol. Geophys. Bioklim., 12, 151-182, 1961.

Wadhams, P. and Squire, V. A.: An ice-water vortex at the edge of the East Greenland Current, J. Geophys. Res., 88, 2770-2780, 1983.

Walczowski, W., Piechura, J., Osinski, R., and Wieczorek, P.: The West Spitsbergen Current volume and heat transport from synoptic observations in summer, Deep-Sea Res., 52, 1374-1391, doi:10.1016/j.dsr.2005.03.009, 2005.

Wessel, P. and Smith, W. H. F.: New, improved version of Generic Mapping Tools released, EOS T. Am. Geophys. U., 79, p. 579, doi:10.1029/98EO00426, 1998.

Wunsch, C.: The North Atlantic general circulation west of $50^{\circ} \mathrm{W}$ determined by inverse methods, Revs. Geophys. Space Phys., 16, 583-620, 1978. 